\title{
Fire Incidents Involving Flammable Liquids, Gas, and Dry Explosives
}

Elaine A. Tyrrell

Center for Fire Research

Institute for Applied Technology

National Bureau of Standards

Washington, D. C. 20234

October 1975

Final

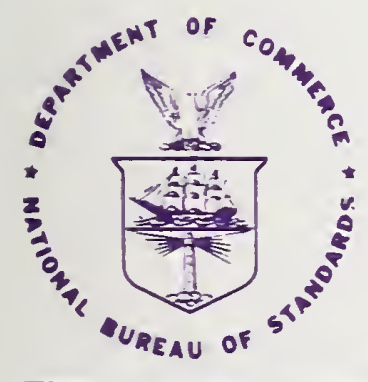

U S. DEPARTMENT OF COMMERCE

NATIONAL BUREAU OF STANDARDS 


\section{FIRE INCIDENTS INVOLVING}

FLAMMABLE LIQUIDS, GAS, AND

DRY EXPLOSIVES

Elaine A. Tyrrell

Center for Fire Research

Institute for Applied Technology

National Bureau of Standards

Washington, D. C. 20230

October 1975

Final

U.S. DEPARTMENT OF COMMERCE, Rogers C.B. Morton, Secretary James A. Baker, III, Under Secretary

Dr. Betsy Ancker-Johnson, Assistant Secretary for Science and Technology

NATIONAL BUREAU OF STANDARDS, Emest Ambler, Acting Director 

LIST OF FIGURES

LIST OF TABLES

1. INTRODUCTION . . . . . . . . . . . . . . . . . . . 1

2. FINDINGS . . . . . . . . . . . . . . . . . . . . . . 3

2.1. Intermediary Material Involvement. . . . . . . . . . . 3

2.2. Victim Involvement . . . . . . . . . . . . . . . . 3

2.2.1. Age and Sex of Persons Involved in Flammable

Liquids and Explosive Products Incidents . . . . 3

2.2.1.1. Selected Parameters for Children

Involved in Flammable Liquids and

Explosive Products Incidents . . . . 7

2.2.1.2. Selected Parameters for the Elderly

Involved in Flammable Liquids and

Explosive Products Incidents . . . . 10

2.2.2. Age and Sex of Persons Involved by Intermediary Material Category. . . . . . . . . . . . 10

2.2.2.1. Volatile Flammable Liquids Category. . 10

2.2.2.2. Grease and Other Less Volatile

Flammable Liquids Category . . . . . 13

2.2.2.3. Gas Category........... 13

2.2.2.4. Dry Explosives Category. . . . . . 18

2.3. Ignition Sources . . . . . . . . . . . . . . 18

2.3.1. Volatile Flamable Liquids Category. . . . . . . 18

2.3.2. Grease and Other Less Volatile Flamable Liquids Category . . . . . . . . . . . 23

2.3.3. Gas Category . . . . . . . . . . . . 23

2.3.4. Dry Explosives Category. . . . . . . . . . 23

2.4. Ignition-Causing Activities. . . . . . . . . . . . . 24

2.4.1. Volatile Flammable Liquids Category. . . . . . . 24

2.4.2. Grease and Other Less Volatile Flammable

Liquids Category. . . . . . . . . . . 28

2.4.3. Gas Category . . . . . . . . . . . . 28

2.4.4. Dry Explosives Category. . . . . . . . . . . 28

2.5. Known First-to-Ignite Fabric Items . . . . . . . . . . . 29

2.5.1. Ignition Sources . . . . . . . . . . . . 29

2.5.1.1. Volatile Flammable Liquids Category. . 29

2.5.1.2. Grease and Other Less Volatile

Flammable Liquids Category . . . . 33

2.5.1.3. Gas Category . . . . . . . . . 34

2.5.1.4. Dry Explosives Category. . . . . . 34

2.5.2. Age Groups and Sex . . . . . . . . . . . . 34

2.5.2.1. Volatile Flammable Liquids Category. . 38

2.5.2.2. Grease and Other Less Volatile Flamable Liquids Category . . . . . 38

2.5.2.3. Gas Category . . . . . . . . 39

2.5.2.4. Dry Explosives Category...... . 39 iii 
CONTENTS (cont'd)

Page

2.6. Severity of Burn Injury. . . . . . . . . . 40

2.6.1. Volatile Flammable Liquids Category. ..... 40

2.6.2. Grease and Other Less Volatile Flammable Liquids Category . . . . . . . . . 40

2.6.3. Gas Category ............. 40

2.6.4. Dry Explosives Category.......... 44

2.7. Injury Disposition . . . . . . . . . . . 44

2.7.1. Volatile Flammable Liquids Category ..... 44

2.7.2. Grease and Other Less Volatile Flammable Liquids Category . . . . . . . . . 47

2.7.3. Gas Category ............ . 47

2.7.4. Dry Explosives Category......... 47

3. SUMMARY AND DISCUSSION . . . . . . . . . . 47

APPENDIX A. THE FLAMMABLE FABRICS ACCIDENT CASE AND TESTING SYSTEM (FFACTS) . . . . . . . . . . 50

APPENDIX B. CLASSIFICATION SYSTEM USED FOR OBTAINING IGNITION SOURCES AND IGNITION-CAUSING ACTIVITIES . . . . . 51 B.1. IGNITION SOURCES. . . . . . . . . . 51 B.2. IGNITION-CAUSING ACTIVITIES ....... 52 


\section{LIST OF FIGURES}

Page

Figure 1. Male and female involvement in flammable liquids and explosive products incidents by age group. (FFACTS, December 1973) ............ 6

Figure 2. Male and female age distribution for flammable liquids and explosive products incidents and for the U.S. population (expected number of victims superimposed). (FFACTS, December 1973) ...........

Figure 3. Male and female age distribution for volatile flammable liquids incidents and for the U.S. population (expected number of victims superimposed). (FFACTS, December 1973) . . . . . . . . . . . .

Figure 4. Male and female age distribution for grease and other less volatile flammable liquids incidents and for the U.S. population (expected number of victims superimposed). (FFACTS, December 1973) . . . . . . 15

Figure 5. Male and female age distribution for gas incidents and for the U.S. population (expected number of victims superimposed). (FFACTS, December 1973) . . . . 17

Figure 6. Male age distribution for dry explosives incidents and for the U.S. population (expected number of victims superimposed). (FFACTS, December 1973) . . . .

\section{LIST OF TABLES}

Table 1. Distribution of Intermediary Materials for Incidents Found in FFACTS by Categories . . . . . . . . .

Table 2. Age and Sex Distribution of all Victims by Intermediary Material Category (FFACTS, December 1973) . . . . 5

Table 3. Age Distribution by Sex of Persons Involved In Flammable Liquids and Explosive Products Incidents Versus Age Distribution for the U.S. Population (FFACTS, December 1973)

Table 4. Age Distribution by Sex of Persons Involved in Volatile Flammable Liquids Incidents Versus Age Distribution for the U.S. Population (FFACTS, December 1973) . . . . 11 
Page

Table 5. Age Distribution by Sex of Persons Involved in Grease and Other Less Volatile Flammable Liquids Incidents Versus Age Distribution for the U.S. Population (FFACTS, December 1973) . . . . . . . . . . . . . 14

Table 6. Age Distribution by Sex of Persons Involved in Gas Incidents Versus Age Distribution for the U.S. Population (FFACTS, December 1973) . . . . . . . 16

Table 7. Age Distribution by Sex for Persons Involved in Dry Explosives Incidents Versus Age Distribution for the U.S. Population (FFACTS, December 1973) . . . . . 19

Table 8. Ignition Sources by Age Groups and Sex . . . . . . . 21

Table 9. Ignition-Causing Activities by Age Groups and Sex . . 25

Table 10. Known First-to-Ignite Fabric Item Groups by Ignition Source . . . . . . . . . . . . . 30

Table 11. Known First-to-Ignite Fabric Item Groups by Age Group . . . . . . . . . . . . . . . . 35

Table 12. Total Body Area Burned by Age Groups and Sex . . . . . 41

Table 13. Injury Disposition of Victims by Age Groups and Sex • . 45 


\title{
FIRE INCIDENTS INVOLVING FLAMMABLE LIQUIDS, GAS, AND DRY EXPLOSIVES
}

\author{
Elaine A. Tyrrel1 1
}

From the NBS Flammable Fabrics Accident Case and Testing System as of December 1973, flammable liquids, gas, and dry explosives were found to be involved in 832 incidents, injuring 863 victims. Volatile flammable liquids represented 77 percent of the incidents; 72 percent of these liquids were gasoline. Male victims outnumbered females more than 3 to 1 . Young adults, ages 21-45, and youth, ages 13-20, were injured most frequently. Children and youth were injured primarily through what was considered as play activities. Adults generally were injured while engaged in activities traditionally considered as being oriented to the particular sex involved. Streetwear, particularly shirts/blouses, was reported most frequently as igniting first. Thirty-six percent of the fabrics represented in these incidents were contaminated with a flammable liquid. Most of the victims sustained burn injuries covering 1-10 percent of their bodies; only 6 percent sustained burn injuries covering 61 percent or more of their bodies. Most of the victims were hospitalized for treatment of their injuries. Although the very young and the elderly were involved in these incidents less frequently than other age groups, they generally were burned more severely and represented 46 percent of the victims who died in the hospital or were dead on arrival.

Key words: Accidents; burn injuries; burn severity; explosives; fabric fires; FFACTS; flammable liquids; gas; gasoline; ignition-causing activities; ignition sources; injury disposition.

\section{INTRODUCTION}

Among the problems associated with the energy shortages are the accompanying price increases and the tendency of consumers to hoard many of the short-supply fuels. An increasing number of accidents associated with the storage and usage of these forms of energy are being reported via the news media.

IAt the time this work was completed, the author was affiliated with the Center for Fire Research, National Bureau of Standards. Ms. Tyrrell is presently working at the Consumer Product Safety Commission. 
In 1973, an estimated $24,600^{2}$ people sought hospital emergency room attention for injuries sustained from flammable liquids 3 . Approximately 60 percent of these injuries were attributable to gasoline, 18 percent to lighter fluid, 17 percent to kerosene, and 5 percent to charcoal starter fluid.

Customarily, cases involving these fuels as well as other flammable liquids have been excluded from consideration when the National Bureau of Standards Flammable Fabrics Accident Case and Testing System (FFACTS) 4 has been searched for various fabric-related studies. It was theorized that if fabric items from these cases were being ignited because of contamination with a flammable liquid, they should not be compared with those fabric items that had been ignited directly from a heat. source, such as matches, lighters, kitchen ranges, heaters, electrical wiring, etc., as the involvement of a flammable liquid obscured the ignition hazard of these fabric items.

The FFACT System was searched in December 1973 for incidents 5 involving flammable liquids and other explosive-type products, all of which were coded as intermediary materials 6 because of the role they played in the ignition sequence. The four categories of intermediary materials searched for specifically were highly volatile flammable liquids, grease and other less volatile flammable liquids, gas, and dry explosives. From a data base of 3,043 cases, 863 victims were found who were involved in 832 separate incidents where the above mentioned intermediary materials were represented in the ignition sequence.

Because nearly one-fourth of the cases in FFACTS were identified with flammable liquids and other explosive products, this study was undertaken to determine what patterns or trends may exist which might aid in the reduction of accidents associated with these materials. It should be noted that the incidents chosen for FFACTS are not selected on a statistical basis and therefore do not constitute a statistically representative sample of all fabric fire accidents in the United States. Thus, the percentages and any comparisons of percentages when used in the findings of this report cannot be considered as typical or conclusive.

An estimated number of injuries for calendar year 1973 based on flammable liquid accident reports from the 119 hospitals participating in the National Electronic Injury Surveillance System (NEISS) of the Consumer Product Safety Commission.

3 Only a few of the more volatile flammable liquids were considered for this estimate where it was felt that the injuries represented would be primarily burn injuries as opposed to ingestion, etc. which are also collected by NEISS.

${ }^{4}$ See appendix A for a description of the FFACTS data base.

${ }^{5}$ An incident is defined as a single ignition from a single heat source 6 which may involve one or more fabric items and/or persons.

${ }^{6}$ An intermediary material is a non-fabric item which is ignited by the ignition source and in turn ignites fabric items, thereby forming a link in the causal chain. 


\section{FINDINGS}

\subsection{Intermediary Material Involvement}

The distribution of these 832 incidents by intermediary material categories is shown in table 1. Volatile flammable liquids, such as gasoline, kerosene, lighter fluid, etc., represented 645 ( 77 percent) of the incidents followed by gas which was involved in 133 (16 percent) of the incidents. Grease and other less volatile flammable liquids, such as cooking grease, paraffin, etc., and dry explosives, such as gunpowder, firecrackers, etc., were involved in only 40 (5 percent) and 14 (2 percent) of the incidents, respectively.

Gasoline was the single most frequently reported volatile flammable liquid, representing 462 (72 percent) of the 645 incidents recorded for the category. In comparison, lighter fluid represented 36 ( 6 percent) of the incidents; alcohol and paint thinner, each represented 4 percent of the incidents with 27 and 23 incidents, respectively, being reported; and solvents, adhesives, and kerosene, each represented 2 percent of the incidents with 13 incidents each being reported for solvents and adhesives and 11 incidents being reported for kerosene.

Cooking grease was the major component of the grease and other less volatile flammable liquids category, representing 30 (75 percent) of the incidents in the category. Coal dust and gunpowder were reported most frequently for the dry explosives, each representing 3 (21 percent) of the incidents reported for the category.

\subsection{Victim Involv́ement}

2.2.1. Age and Sex of Persons Involved in Flammable Liquids and Explosive Products Incidents

of the 863 victims in these 832 incidents, males numbered 666 (77 percent) and females numbered 197 (23 percent). The age and sex distribution for these 863 victims are tabulated by intermediary material category in table 2. For purposes of analysis, six age groups were chosen which roughly indicate six types of behavior patterns. The age groups represent infants and toddlers, ages 0-5; children, ages 6-12; youth, ages 13-20; young adults, ages 21-45; adults, ages 46-65; and the elderly, age 66 and over. These victims are separated by sex in figure 1 where the histograms for each sex represent the number of victims by age group who were involved in these four categories of incidents.

Males were represented most frequently in all age groups in these 832 incidents. By intermediary material categories, males were injured most frequently in the volatile flammable liquids incidents in all age groups. Male injuries dominated in the gas and dry explosives categories, but females were injured most frequently in the grease and other less volatile flammable liquids incidents in a nearly 2 to 1 ratio over the males. 
Table 1. Distribution of Intermediary Materials

for Incidents Found in FFACTS by Categories

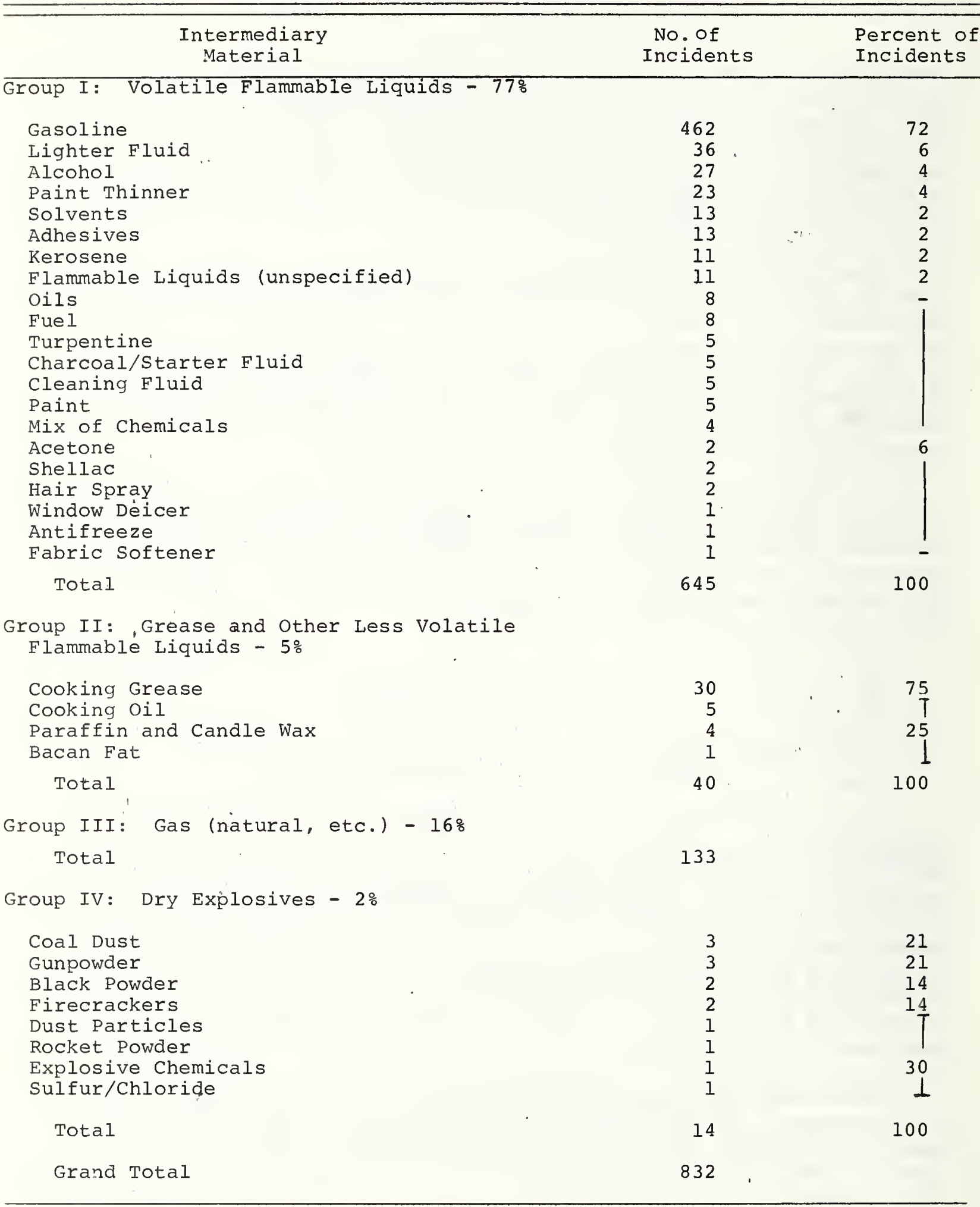




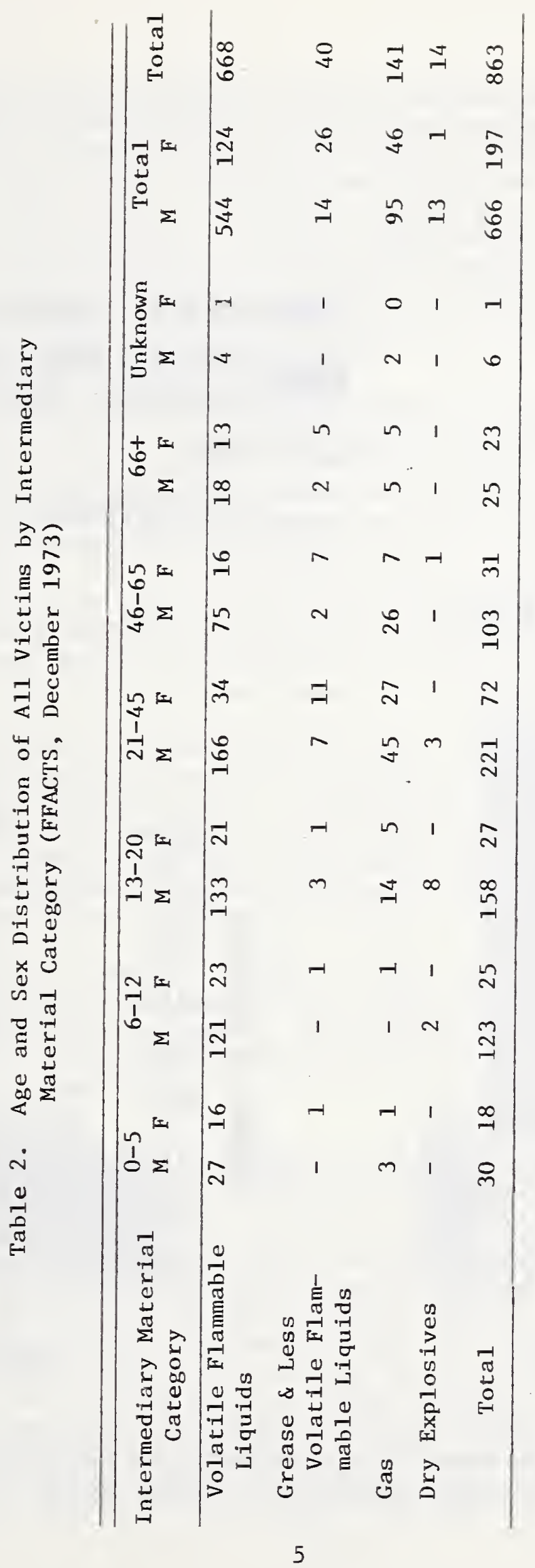




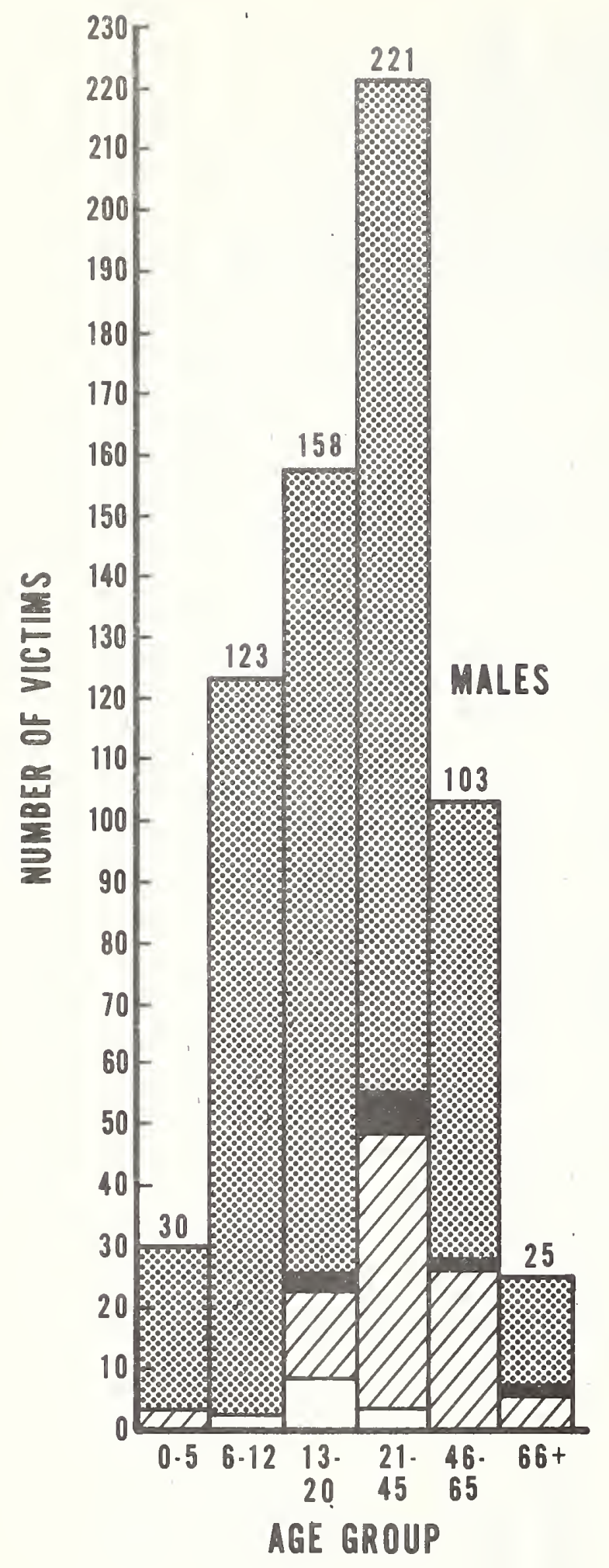

\section{VOLATILE FLAMMABLE LIQUIDS GREASE \& OTHER LESS VOLATILE FLAMMABLE LIQUIDS EZZGAS $\square$ DRY EXPLOSIVES}

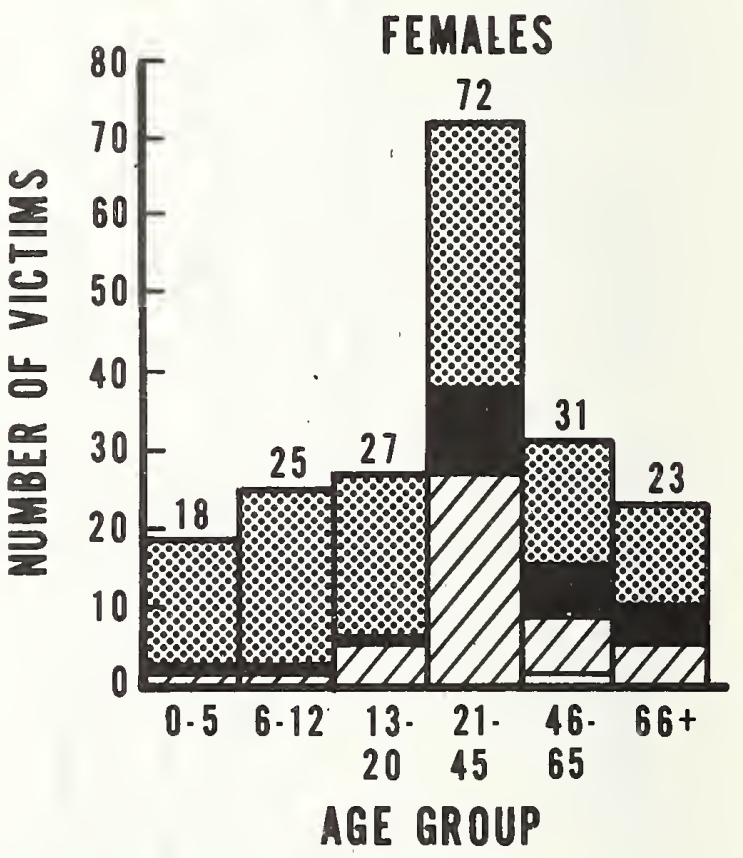

Figure 1. Male and female involvement in flammable liquids and explosive products incidents by age group (FFACTS, December 1973). 
The total number of victims for each sex was redistributed over the six age groups ${ }^{7}$ in proportion to their representation in the U.S. population. This information is shown in table 3. The resulting distributions indicate the number of victims which might be expected for each age group if these types of incidents occurred proportionately throughout the population as a whole. A visual representation of these data is shown in figure 2 where the number of victims which might be expected for each age group (if the victims were distributed uniformly over the age groups in proportion to their representation in the U.S. population) are superimposed over the histograms from figure 1 .

Males in the 6-45 age range were injured far more frequently than would have been expected for their respective age groups if the victims were distributed proportionately over the male population. Males in the 6-12 age group were injured" often because of their tendencies to "experiment" with flammable liquids and other explosive products. Males in the 13-20 age group were involved frequently with many of the same types of activities, but on a more sophisticated level. Some of the activities involving these older youths may have been assigned chores, but probably should still be considered as play activities in most instances. Males in the 21-45 age group were involved in a variety of activities around the home for which many of these hazardous products are frequently used.

Only the females in the 21-45 age group were injured more frequently than would have been expected if the incidents were distributed proportionately over the female population. Although they were involved most frequently in volatile flammable liquids incidents, they were also frequently represented in the gas incidents. Females in this age group also were involved more frequently in grease and other less volatile flammable liquids incidents than any other age group for either sex.

From the FFACTS data it can be seen that the involvement of victims in the youngest and oldest age groups for both sexes is rather low when compared to the other age groups. This may be indicative of the level of physical development in the young and a tendency toward physical deterioration in the elderly.

2.2.1.1. Selected Parameters for Children Involved in Flammable Liquids and Explosive Products Incidents

The incidents involving infants and children through the age of 12 were analyzed for victim solitude at ignition, the presence of adult supervision at ignition, and time of day of incident. Thirty-eight (79 percent) of the 48 infants and toddlers and 110 ( 77 percent) of the 148 children ages 6-12 were not alone during the ignition sequence. The majority of these children were with other children instead of adults. Ten of the infants and toddlers and 35 of the remaining older children were alone either at ignition or during the entire course of the accident.

${ }^{7}$ The victims of unknown ages for both sexes were excluded from table 3 . 
Table 3. Age Distribution by Sex of Persons Involved In Flammable Liquids and Explosive Products Incidents Versus Age Distribution for the U.S. Population (FFACTS, December 1973)

a. Males

\begin{tabular}{cccc}
\hline Age Group & $\begin{array}{c}\text { Number of } \\
\text { Victims }\end{array}$ & $\begin{array}{c}\text { Percent of U.S. } \\
\text { Population* }\end{array}$ & $\begin{array}{c}\text { Expected Number of } \\
\text { Victims based on } \\
\text { Population Percentage** }\end{array}$ \\
\hline $0-5$ & 30 & 11 & 73 \\
$6-12$ & 123 & 15 & 99 \\
$13-20$ & 158 & 16 & 106 \\
$21-45$ & 221 & 31 & 204 \\
$46-65$ & 103 & 19 & 53 \\
$66+$ & 25 & 8 & 660 \\
Total & $660^{\dagger}$ & 100 & \\
\hline
\end{tabular}

b. Females

\begin{tabular}{cccc}
\hline Age Group & $\begin{array}{c}\text { Number of } \\
\text { Victims }\end{array}$ & $\begin{array}{c}\text { Percent of U.S. } \\
\text { Population* }\end{array}$ & $\begin{array}{c}\text { Expected Number of } \\
\text { Victims based on } \\
\text { Population Percentage** }\end{array}$ \\
\hline $0-5$ & 18 & 10 & 20 \\
$6-12$ & 25 & 13 & 25 \\
$13-20$ & 27 & 15 & 29 \\
$21-45$ & 72 & 31 & 22 \\
$46-65$ & 31 & 20 & 22 \\
$66+$ & 23 & 11 & 196 \\
Total & $196^{\dagger}$ & 100 & \\
\hline
\end{tabular}

${ }^{*}$ Figures are based on 1970 U.S. Bureau of Census statistics. $* *$ Expected Number $=$ Total Number of Victims $\mathrm{x}$ Respective Percent of of Victims $=$ in FFACTS

tVictims of unknown ages are excluded. 

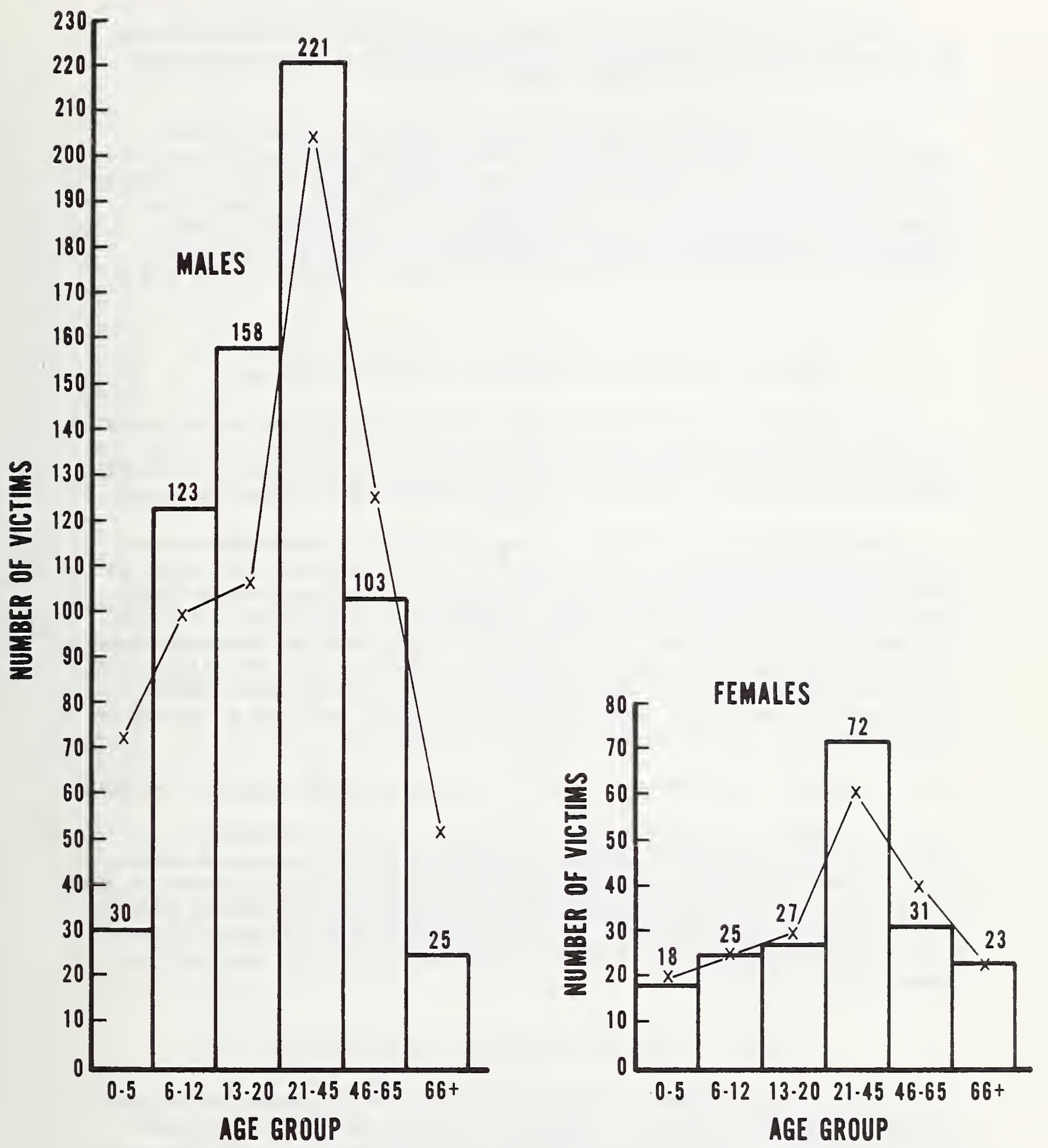

Figure 2. Male and female age distribution for flammable liquids and explosive products incidents and for the U.S. population (expected number of victims superimposed). (FFACTS, December 1973) 
Approximately 75 percent of these 196 children were not receiving adult supervision at the time of the accident; 31 of these were under the age of six and 115 were 6-12 years of age.

Most of the accidents involving the children in these two age groups occurred during the afternoon hours between noon and 6 p.m.; 105 (54 percent) of the children were injured during these hours. In comparison, 46 (23 percent) children were injured during the evening hours between $6 \mathrm{p} . \mathrm{m}$. and midnight, 39 (20 percent) children were injured during the morning hours between $6 \mathrm{a}, \mathrm{m}$. and noon, and 6 ( 3 percent) children were injured at night between the hours of midnight and 6 a.m.

\subsubsection{Selected Parameters for the Elderly Involved in} Flammable Liquids and Explosive Products Incidents

The incidents involving the elderly were analyzed for victim solitude at ignition, marital status, and general location of accident. With the exception of two incidents which took place in a nursing home, these victims were at home (in a house or apartment) when the incident occurred.

Twenty-three ( 48 percent) of these 48 elderly victims were alone during the entire course of the accident, 16 (33 percent) were alone at ignition, and 7 (15 percent) were reported as not being alone at ignition. More males than females were reported as being either not alone or alone only at ignition, but more females were reported as being alone during the entire course of the accident. The fact that the majority of the males were reported as being married at the time of the incident while most of the females were reported as widowed may have a bearing on the breakdown by sex of victim solitude at ignition.

\subsubsection{Age and Sex of Persons Involved by Intermediary Material Category}

These data were analyzed by intermediary material categories in tables 4-7 where the total number of victims for both sexes was redistributed over the age groups in proportion to their represertation in the U.S. population. Visual representations (figures 3-6) were then made for each sex by intermediary material category and the number of victims which might be expected for each age group were superimposed over the respective histograms.

\subsubsection{Volatile Flammable Liquids Category}

In table 4 and figure 3, this information is presented for volatile flammable liquids incidents. Males in the 6-12 and 13-20 age groups were injured far more frequently than would have been expected for their age groups if the incidents were distributed proportionately over the male age groups. These males were injured most frequently from what was considered as primarily play activities. Males in the 21-45 age group were represented more frequently than all other age groups in the FFACTS data, but they also represent the largest portion of the male population 
Table 4. Age Distribution by Sex of Persons Involved in Volatile Flammable Liquids Incidents Versus Age Distribution

for the U.S. Population

(FFACTS, December 1973)

a. Males

\begin{tabular}{cccc}
\hline Age Group & $\begin{array}{c}\text { Number of } \\
\text { Victims }\end{array}$ & $\begin{array}{c}\text { Percent of U.S. } \\
\text { Population }\end{array}$ & $\begin{array}{c}\text { Expected Number of } \\
\text { Victims based on } \\
\text { Population Percentage* }\end{array}$ \\
\hline $0-5$ & 27 & 11 & 59 \\
$6-12$ & 121 & 15 & 81 \\
$13-20$ & 133 & 16 & 87 \\
$21-45$ & 166 & 31 & 167 \\
$46-65$ & 75 & 19 & 403 \\
$66+$ & 18 & 8 & 540 \\
Total & 540 & 100 & 4
\end{tabular}

b. Females

\begin{tabular}{cccc}
\hline Age Group & $\begin{array}{c}\text { Number of } \\
\text { Victims }\end{array}$ & $\begin{array}{c}\text { Percent of U.S. } \\
\text { Population* }\end{array}$ & $\begin{array}{c}\text { Expected Number of } \\
\text { Victims based on } \\
\text { Population Percentage** }\end{array}$ \\
\hline $0-5$ & 16 & 10 & 12 \\
$6-12$ & 23 & 13 & 16 \\
$13-20$ & 21 & 15 & 38 \\
$21-45$ & 34 & 31 & 25 \\
$46-65$ & 16 & 20 & 14 \\
$66+$ & 13 & 11 & 123 \\
Total & 123 & 100 &
\end{tabular}

\footnotetext{
*Figures are based on 1970 U.S. Bureau of Census statistics. ${ }^{*}$ Expected Number $=$ Total Number of Victims ${ }_{2:}$ Respective Percent of of Victims $=$ in FFACTS U.S. Population

tVictims of unknown ages are excluded.
} 


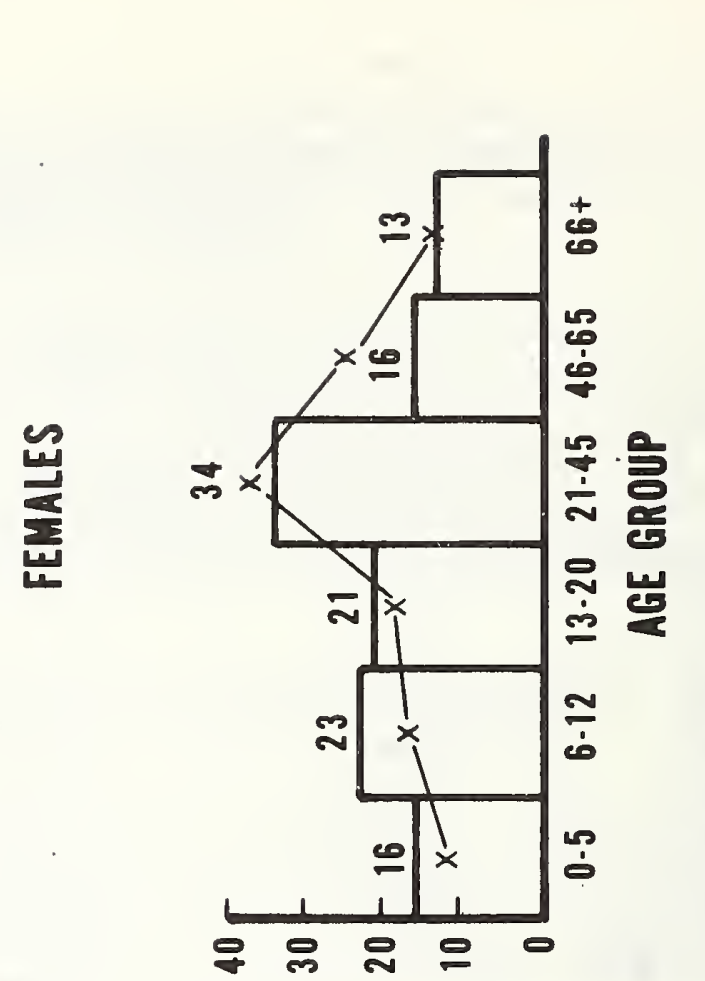

SWILJIA JO УJgWกN

命

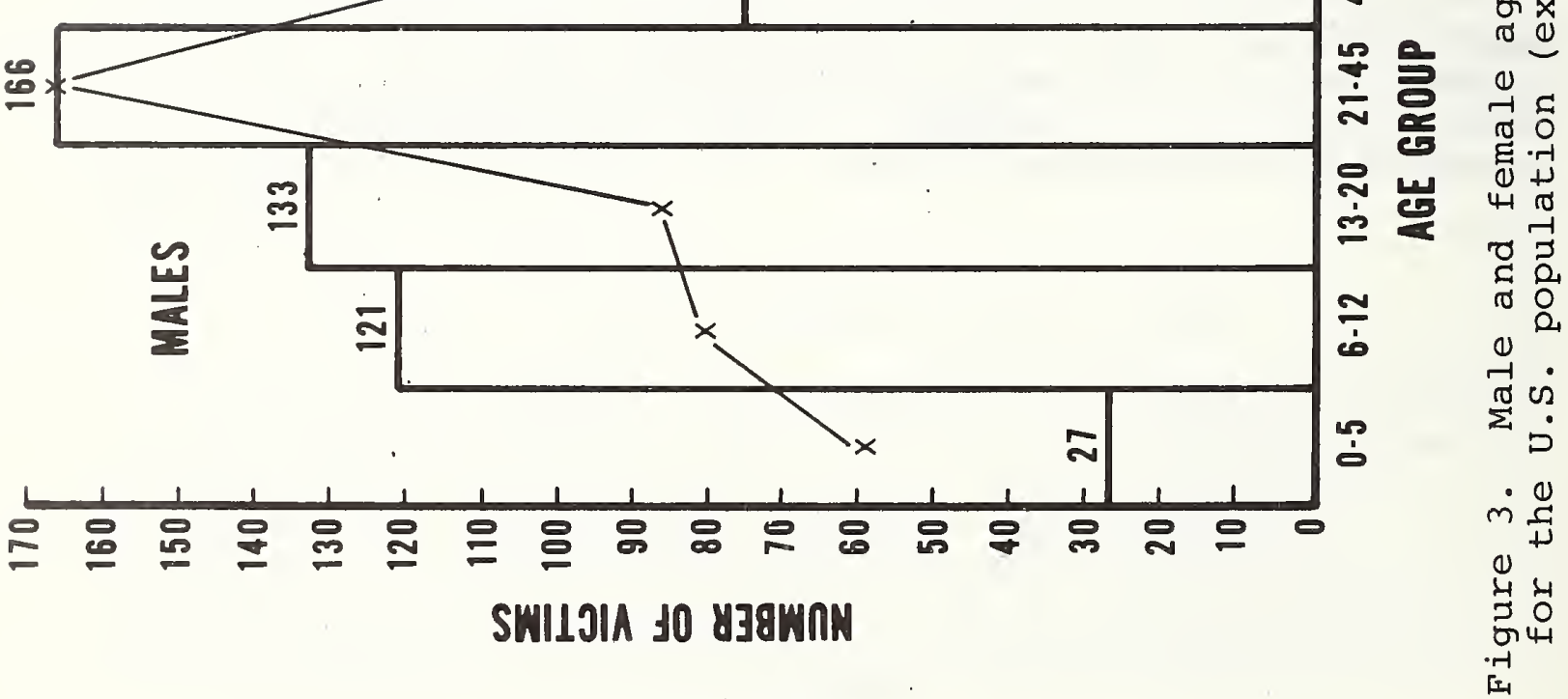


among the six age groups used in this paper. Hence, these males were injured about as frequently as would have been expected if the volatile flammable liquids incidents for the male victims were distributed proportionately over the age groups.

Females only represented approximately 19 percent of the victims involved in volatile flammable liquids incidents. Among females, those through the age of 20 were injured most frequently in proportion to their representation in the female population.

\subsubsection{Grease and Other Less \\ Volatile Flammable Liquids Category}

In table 5 and figure 4, this information is displayed for grease and other less volatile flammable liquids. Most of the incidents described in this category were cooking related, where cooking grease or cooking oil ignited and the victims were injured as the result of either carrying or transporting the burning liquid; spilling, splashing or splattering the liquid; or knocking over or dropping the container of burning liquid.

Females comprised 65 percent of the victims in this intermediary material category. Forty-two percent of the females were in the 21-45 age group, 27 percent were in the 46-65 age group, and 19 percent were 66 years old and over. The victims in these age groups were injured most frequently in proportion to their representation in the female population.

Males in the 21-45 age group were injured more frequently than males in any other age group and more frequently than would have been expected if the incidents had been distributed proportionately over all age groups.

\subsubsection{Gas Category}

In table 6 and figure 5, this information is presented for the gas incidents. A11 of the incidents in this intermediary material category were the result of an explosion.

The most frequent victims of these incidents were males primarily in the 13-65 age range. Males in the 13-20 age group were injured about as frequently as would be expected if the gas incidents were distributed proportionately across the male population. Males in the 21-45 and 46-65 age groups were injured much more frequently than would have been expected. Males in all 3 age groups were injured most often while attempting to light a pilot light in a furnace, water heater, kitchen range, etc. This activity would probably be assumed by males primarily in the 21-45 and 46-65 age groups as part of home maintenance. 
Table 5. Age Distribution by Sex of Persons Involved in Grease and Other Less Volatile Flammable Liquids Incidents Versus Age Distribution for the U.S. Population

(FFACTS, December 1973)

\section{a. Males}

\begin{tabular}{cccc}
\hline Age Group & $\begin{array}{c}\text { Number of } \\
\text { Victims }\end{array}$ & $\begin{array}{c}\text { Percent of U.S. } \\
\text { Population }\end{array}$ & $\begin{array}{c}\text { Expected Number of } \\
\text { Victims Based on } \\
\text { Population Percentage** }\end{array}$ \\
\hline $0-5$ & 0 & 11 & 2 \\
$6-12$ & 0 & 15 & 2 \\
$13-20$ & 3 & 16 & 4 \\
$21-45$ & 7 & 31 & 3 \\
$46-65$ & 2 & 19 & 1 \\
$66+$ & 2 & 8 & 14 \\
Total & 14 & 100 & \\
\hline
\end{tabular}

b. Females

\begin{tabular}{cccc}
\hline Age Group & $\begin{array}{c}\text { Number of } \\
\text { Victims }\end{array}$ & $\begin{array}{c}\text { Percent of U.S. } \\
\text { Population* }\end{array}$ & $\begin{array}{c}\text { Expected Number of } \\
\text { Victims Based on } \\
\text { Population Percentage** }\end{array}$ \\
\hline $0-5$, & 1 & 10 & 3 \\
$6-12$ & 1 & 13 & 3 \\
$13-20$ & 1 & 15 & 4 \\
$21-45$ & 11 & 31 & 5 \\
$46-65$ & 7 & 20 & 3 \\
$66+$ & 5 & 11 & 26 \\
Total & 26 & 100 & 26 \\
\hline
\end{tabular}

*Figures are based on 1970 U.S. Bureau of Census statistics. **Expected Number $=$ Total Number of Victims ${ }_{\mathrm{x}}$ Respective Percent of of Victims in FFACTS U.S. Population 


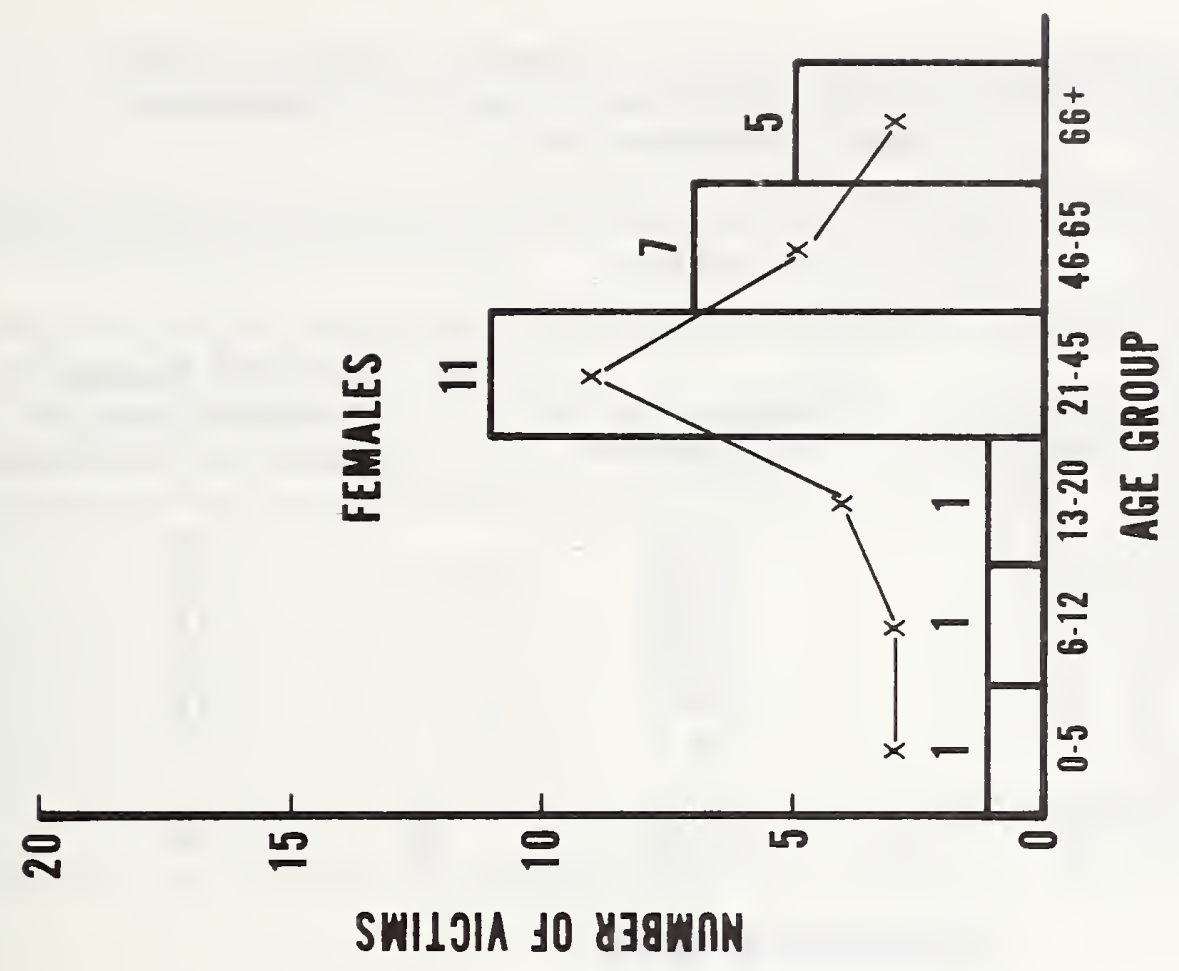

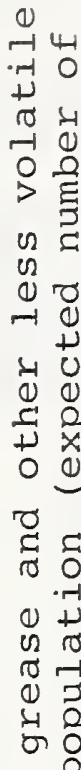

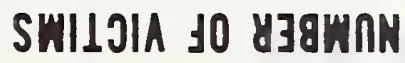

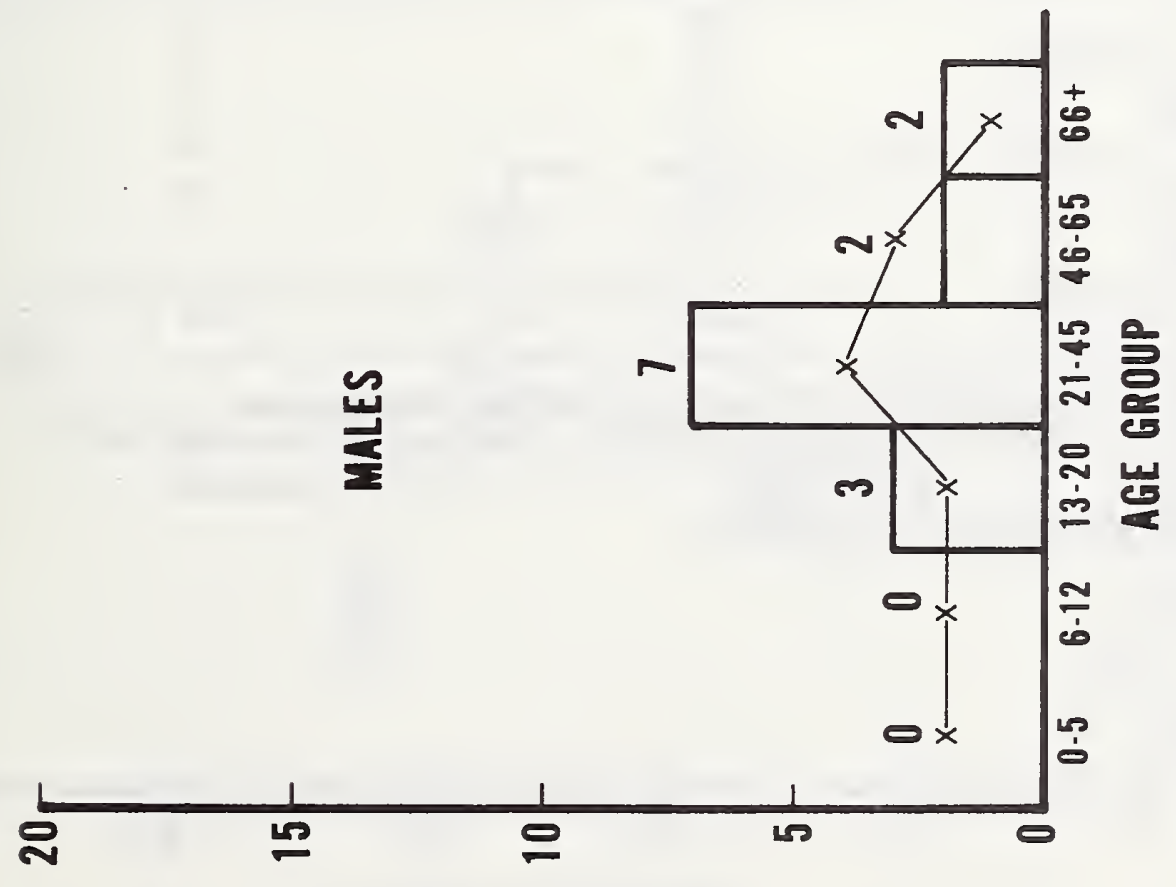

SWILOIA JO y3gwกN 
Table 6. Age Distribution by Sex of Persons Involved in Gas Incidents Versus Age Distribution for the U.S. Population (FFACTS, December 1973)

a. Males

\begin{tabular}{cccc}
\hline Age Group & $\begin{array}{c}\text { Number of } \\
\text { Victims }\end{array}$ & $\begin{array}{c}\text { Percent of U.S. } \\
\text { Population* }\end{array}$ & $\begin{array}{c}\text { Expected Number of } \\
\text { Victims based on } \\
\text { Population Percentage** }\end{array}$ \\
\hline $0-5$ & 3 & 11 & 10 \\
$6-12$ & 0 & 15 & $14^{3 *}$ \\
$13-20$ & 14 & 16 & 29 \\
$21-45$ & 45 & 31 & 18 \\
$46-65$ & 26 & 8 & 7 \\
$66+$ & 5 & 100 & 93 \\
Total & $93^{\dagger}$ & & \\
\hline
\end{tabular}

b. Females

\begin{tabular}{cccc}
\hline Age Group & $\begin{array}{c}\text { Number of } \\
\text { Victims }\end{array}$ & $\begin{array}{c}\text { Percent of U.S. } \\
\text { Population* }\end{array}$ & $\begin{array}{c}\text { Expected Number of } \\
\text { Victims based on } \\
\text { Population Percentage** }\end{array}$ \\
\hline $0-5$ & 1 & 10 & 5 \\
$6-12$ & 1 & 13 & 6 \\
$13-20$ & 5 & 15 & 7 \\
$21-45$ & 27 & 31 & 9 \\
$46-65$ & 7 & 11 & 5 \\
$66+$ & 5 & 100 & 46 \\
\hline
\end{tabular}

*Figures are based on 1970 U.S. Bureau of Census statistics. **Expected Number = Total Number of Victims $\mathrm{x}$ Respective Percent of of Victims $=$ in FFACTS $\mathrm{x}$ U.S. Population

†Victims of unknown ages are excluded. 


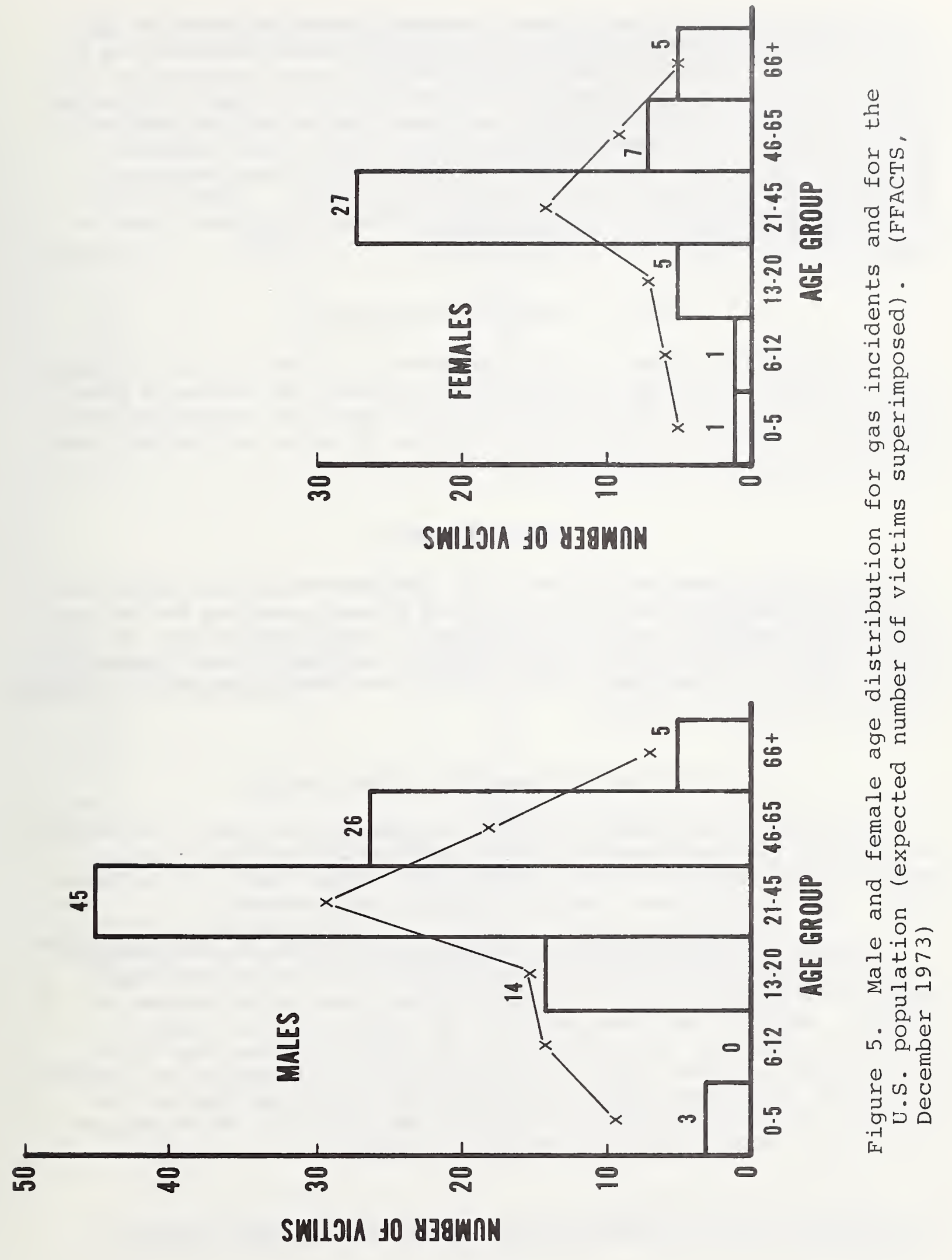


Of the females injured in these incidents, those in the 21-45 age group were represented most often in the FFACTS data and were injured far more frequently than would have been expected for their age group if the incidents had been proportionately distributed over the female population. Most of the women in this age group were described in the case reports as being the female most responsible for the functions of the household. This meant she was the wife, mother, or head of the house (woman with children or others in her care, or woman living alone). These victims were involved most frequently with kitchen ranges, attempting either to ignite the pilot light or use the range.

\subsubsection{Dry Explosives Category}

In table 7 and figure 6, this information is shown for the dry explosives incidents. With the exception of one female, the victims of these accidents were males. Males in the 13-20 age group were represented most frequently. Most of the activities involving the males in this age group were considered as play activities.

\subsection{Ignition Sources}

The ignition sources 8 for these 832 flammable liquids and explosive products incidents are displayed in table 8 by age groups and sex for each intermediary material category. The class of open fires includes charcoal grills, camp fires, fireplaces, incinerators, bonfires, fires to clear trash, leaves or other debris, etc. The class of smoking materials includes cigarettes, cigars, and pipes.

\subsubsection{Volatile Flammable Liquids Category}

For the volatile flammable liquids incidents, open fires, and matches and lighters were the ignition sources reported most frequently, representing 172 (27 percent) and 150 (23 percent), respectively, of the incidents. Matches alone were involved in 120 of the incidents.

The most frequent victims in incidents involving both of these ignition sources were males in the 6-12 age group with 43 incidents being reported for open fires and 47 incidents being reported for matches and lighters. Males in the 13-20 and 21-45 age groups also were injured frequently with these two ignition sources, although males, ages 21-45, were involved with open fires far more often than with matches and lighters. "Open fires" mean trash, leaf, and other fires in an open area for the 6-12 year old males; incinerator fires for the 13-20 year old males; and charcoal grill fires for the $21-45$ year old males.

8

See appendix B for the classification system used to obtain ignition sources. 
Table 7. Age Distribution by Sex for Persons Involved in Dry Explosives Incidents Versus Age Distribution for the U.S. Population

(FFACTS, December 1973)

\section{a. Males}

\begin{tabular}{cccc} 
Age Group & $\begin{array}{c}\text { Number of } \\
\text { Victims }\end{array}$ & $\begin{array}{c}\text { Percent of U.S. } \\
\text { Population }\end{array}$ & $\begin{array}{c}\text { Expected Number of } \\
\text { Victims based on } \\
\text { Population Percentaget }\end{array}$ \\
\hline $0-5$ & 0 & 11 & 1 \\
$6-12$ & 2 & 15 & 2 \\
$13-20$ & 8 & 16 & 4 \\
$21-45$ & 3 & 31 & 3 \\
$46-65$ & 0 & 19 & 1 \\
$66+$ & 0 & 8 & 13 \\
Total & 13 & 100 & 13 \\
\hline
\end{tabular}

b. Females

\begin{tabular}{cccc}
\hline Age Group & $\begin{array}{c}\text { Number of } \\
\text { Victims }\end{array}$ & $\begin{array}{c}\text { Percent of U.S. } \\
\text { Population* }\end{array}$ & $\begin{array}{c}\text { Expected Number of } \\
\text { Victims based on } \\
\text { Population Percentage }\end{array}$ \\
\hline $0-5$ & 0 & 10 & 0 \\
$6-12$ & 0 & 13 & 0 \\
$13-20$ & 0 & 15 & 0 \\
$21-45$ & 0 & 31 & 0 \\
$46-65$ & 1 & 20 & 0 \\
$66+$ & 0 & 11 & 0 \\
Total & 1 & 100 & 0 \\
\hline
\end{tabular}

*Figures are based on 1970 U.S. Bureau of Census statistics.

**Expected Number $=$ Total Number of Victims $x$ Respective Percent of of Victims $=$ in FFACTS U.S. Population 


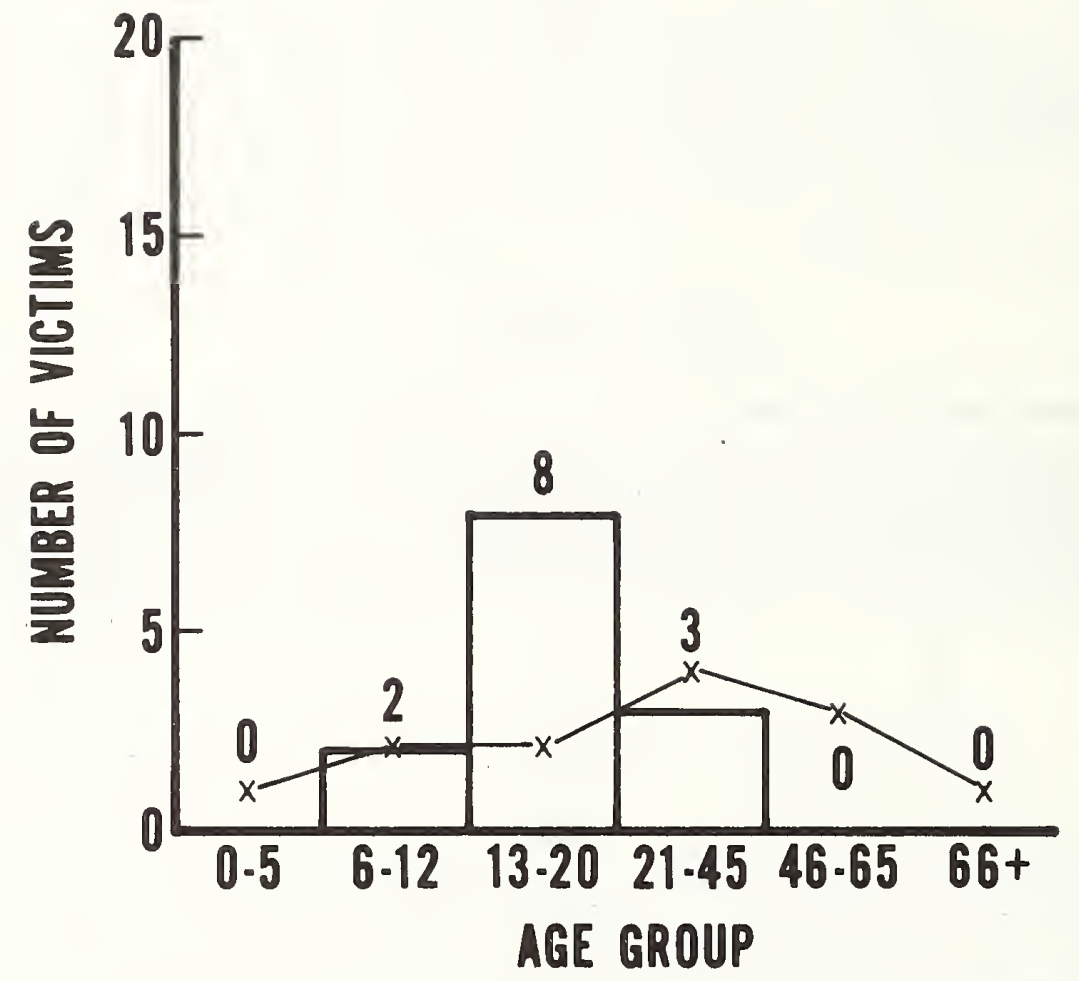

Figure 6. Male age distribution for dry explosives incidents and for the U.S. population (expected number of victims superimposed). (FFACTS, December 1973) 
Table 8. Ignition Sources by Age Groups and Sex

a. Volatile Flamable Liquids

\begin{tabular}{|c|c|c|c|c|c|c|c|c|c|c|c|c|c|c|c|}
\hline \multirow{2}{*}{ Ignition Source } & \multicolumn{2}{|c|}{$0-5$} & \multicolumn{2}{|c|}{$6-12$} & \multicolumn{2}{|c|}{$13-20$} & \multicolumn{2}{|c|}{$21-45$} & \multicolumn{2}{|c|}{$46-65$} & \multicolumn{2}{|c|}{$66+$} & \multicolumn{2}{|c|}{ Unknown } & \multirow{2}{*}{ Total } \\
\hline & M & $\mathrm{F}$ & M & $\mathrm{F}$ & M & F & M & $\mathrm{F}$ & M & F & M & F & M & $\mathrm{F}$ & \\
\hline Furnace & 5 & 1 & 2 & - & 2 & 1 & 1 & 1 & 2 & - & - & 1 & - & - & 16 \\
\hline Space Heater & 1 & 1 & 3 & 1 & 3 & 1 & 5 & 2 & 3 & - & - & - & - & - & 20 \\
\hline Hot Water Heater & 6 & 4 & 6 & 1 & 10 & 4 & 15 & 1 & 5 & 2 & 1 & 1 & 2 & - & 58 \\
\hline Electric Range & - & - & - & - & - & - & - & - & - & - & - & 1 & - & - & 1 \\
\hline Gas Range & - & - & 1 & 1 & 3 & - & 7 & 5 & 1 & 1 & 2 & 2 & - & - & 23 \\
\hline Appliances (0ther) $)_{*}^{*}$ & - & 1 & - & - & 6 & - & 4 & - & 2 & - & - & - & - & - & 13 \\
\hline Electrical Wiring & - & - & 1 & 1 & 3 & - & 4 & - & 3 & - & - & - & - & - & 12 \\
\hline Lantern/Candle & 1 & - & 3 & 3 & 1 & 4 & 2 & 3 & 1 & - & - & - & 1 & - & 19 \\
\hline Open Fire & 5 & 4 & 43 & 9 & 34 & 2 & 36 & 8 & 18 & 4 & 5 & 3 & 1 & - & 172 \\
\hline Smoking Materials & - & - & - & - & 1 & - & 2 & - & 3 & 2 & - & - & - & - & 8 \\
\hline Matches \& Lighters & 8 & 3 & 47 & 6 & 33 & 5 & 20 & 8 & 6 & 3 & 6 & 5 & - & - & 150 \\
\hline \multicolumn{16}{|c|}{ Cutting/Welding Torches } \\
\hline \& Other Work Tools & - & - & 1 & - & 4 & - & 17 & - & 7 & - & 1 & - & - & - & 30 \\
\hline Combustion Engine & 1 & 1 & 2 & 1 & 11 & 2 & 27 & 1 & 17 & - & 3 & - & - & - & 66 \\
\hline Fireworks & - & - & 1 & - & - & - & - & - & - & - & - & - & - & - & 1 \\
\hline Other & - & - & 5 & - & 5 & - & 11 & - & 2 & 2 & - & - & - & 1 & 26 \\
\hline Total Known & 27 & 15 & 115 & 23 & 116 & 19 & 151 & 29 & 70 & 14 & 18 & 13 & 4 & 1 & 615 \\
\hline Unknown & - & 1 & 3 & - & 11 & 1 & 6 & 2 & 5 & 1 & - & - & - & - & 30 \\
\hline Total & 27 & 16 & 118 & 23 & 127 & 20 & 157 & 31 & 75 & 15 & 18 & 13 & 4 & 1 & 645 \\
\hline
\end{tabular}

${ }_{*}^{*}$ Includes other heaters and ranges.

Includes light bulbs and lamps.

b. Grease and Other Less Volatile Flammable Liquids

\begin{tabular}{|c|c|c|c|c|c|c|c|c|c|c|c|c|c|c|c|}
\hline \multirow{2}{*}{ Ignition Source } & \multicolumn{2}{|c|}{$0-5$} & \multicolumn{2}{|c|}{$6-12$} & \multicolumn{2}{|c|}{$13-20$} & \multicolumn{2}{|c|}{$21-45$} & \multicolumn{2}{|c|}{$46-65$} & \multicolumn{2}{|c|}{$66+$} & \multicolumn{2}{|c|}{ Unknown } & \multirow{2}{*}{ Total } \\
\hline & M & F & $M$ & F & M & F & M & F & M & F & M & F & M & $\mathrm{F}$ & \\
\hline Electric Range & - & - & - & 1 & - & 1 & 2 & 7 & - & 2 & - & 1 & - & - & 14 \\
\hline Gas Range & - & 1 & - & - & 1 & - & - & 1 & 1 & 2 & 2 & 2 & - & - & 10 \\
\hline Appliances (Other)* & - & - & - & - & 2 & - & 5 & 2 & - & 2 & - & 1 & - & - & 12 \\
\hline Lantern/Candle & - & - & - & - & - & - & - & - & - & 1 & - & - & - & - & 1 \\
\hline Open Fire & - & - & - & - & - & - & - & - & - & - & - & 1 & - & - & 1 \\
\hline Other & - & - & - & - & - & - & - & - & 1 & - & - & - & - & - & 1 \\
\hline Total Known & - & 1 & - & 1 & 3 & 1 & 7 & 10 & 2 & 7 & 2 & 5 & - & - & 39 \\
\hline Unknown & - & - & - & - & - & - & - & 1 & - & - & - & - & - & - & 1 \\
\hline Total & - & 1 & - & 1 & 3 & 1 & 7 & 11 & 2 & 7 & 2 & 5 & - & - & 40 \\
\hline
\end{tabular}

*Includes unspecified and other ranges. 
Table 8. Ignition Sources by Age Groups and Sex (continued)

c. Gas

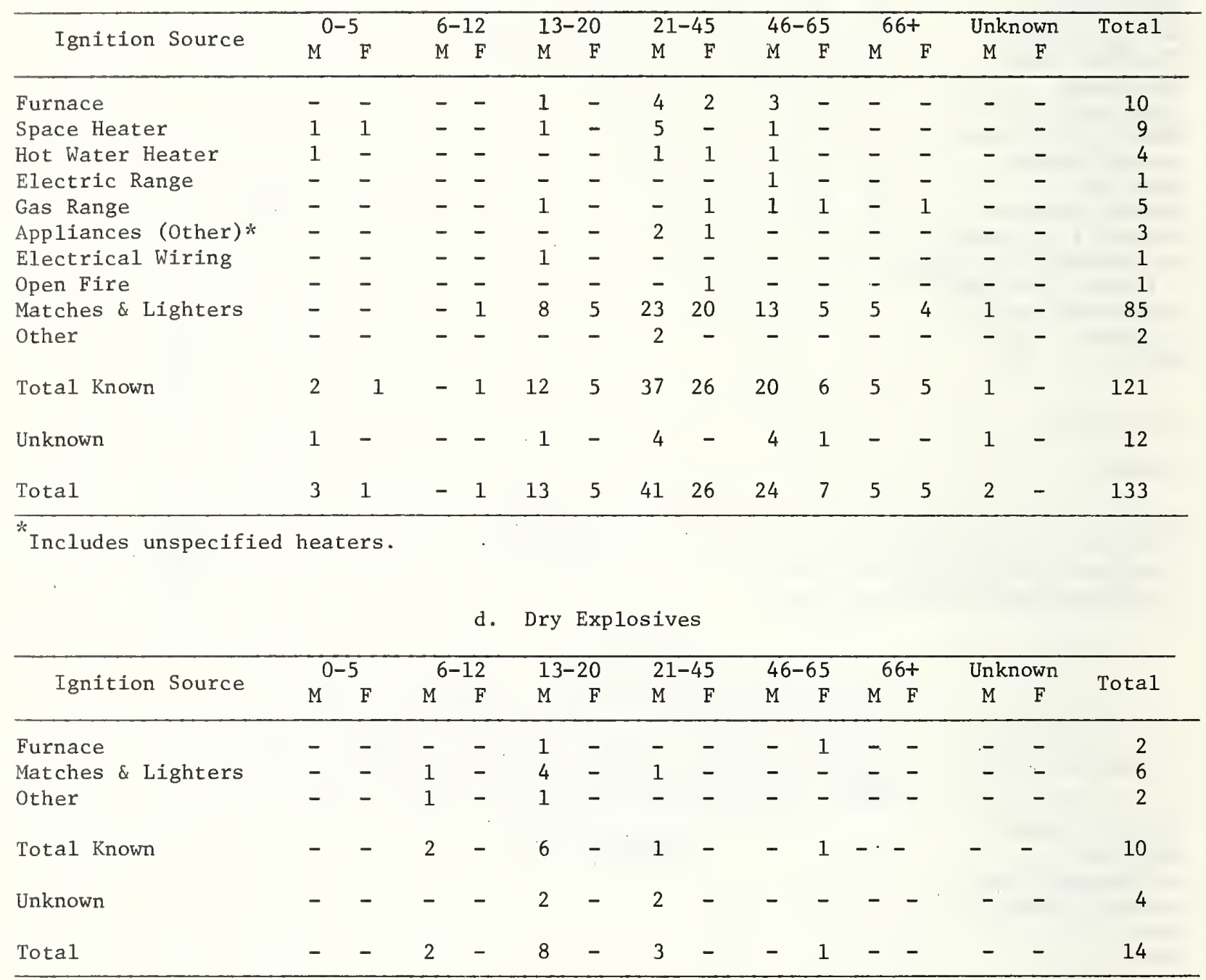


Internal combustion engines were the third most frequently reported ignition source representing 66 (10 percent) of the incidents. Males in the 21-45 age group followed by males in the 46-65 age group were the most frequent victims of this ignition source.

Females, in general, were injured most frequently from their involvement with open fires. Females in the 6-12 age group followed by those in the 21-45 age group were reported most often. Females in the 6-12 age group were involved primarily with fires started in an open area whereas females in the 21-45 age group were involved mainly with either charcoal grills or matches and lighters.

Males in the 0-5 age group were involved most often with matches and lighters followed by hot water heaters, furnaces, and open fires. Females in this age group were involved with hot water heaters and open fires most frequently followed by matches and lighters. These four classes of ignition sources represent 83 percent of the victims in this age group.

The elderly were involved most often with matches and lighters. For the males, this ignition source was closely followed by smoking materials which included cigarettes, cigars, pipes, etc.

\subsubsection{Grease and Other Less Volatile Flammable Liquids Category}

For the grease and other less volatile flammable liquids incidents, kitchen ranges were involved in 36 (90 percent) of the incidents with electric ranges predominating. Adults, ages 21 and over, were the chief victims of the incidents for this category, with 68 percent of these adults being female. By sex, both males and females in the $21-45$ age group were involved most of ten in these incidents followed by females in the 46-65 and the 66 and over age groups with the incident rate decreasing with increasing age.

\subsubsection{Gas Category}

Matches and lighters were reported most frequently as an ignition source in the gas incidents representing 85 (64 percent) of the incidents. Matches alone were involved in 75 of these incidents. Both males and females in the 21-45 age group were reported as being involved with this ignition source most frequently followed by males in the 46-65 age group. Matches and lighters were also reported most frequently for males in the 13-20 and the 66 and over age groups.

\subsubsection{Dry Explosives Category}

As with the gas incidents, matches and lighters were reported most frequently as the ignition source in the dry explosives incidents, representing 6 ( 43 percent) of the incidents. Matches alone were involved in 5 of the incidents. Males in the 13-20 age group were the chief victims of the dry explosives incidents. 


\subsection{Ignition-Causing Activities}

From a review of these case histories, it was noted that they often contained information regarding the precise action which led to the ignition -- detailed information which cannot be retrieved from the computerized data file. It was also observed that these specific activities appeared repeatedly in these incidents which suggested that categorization of these activities might be possible.

A classification 1ist $^{9}$ was devised for obtaining these activities from the 832 flammable liquids and explosive products incidents. In the following sub-sections, the activities which were found by using this classification listing are reported.

Because the specific activity which led to the ignition sequence was coded for each incident, the activity may not necessarily indicate the activity of the primary victim 10 who represents the incident. The activities for these incidents are tabulated in table 9 for each intermediary material category by age groups and sex for the representative victim.

\subsubsection{Volatile Flammable Liquids Category}

For the volatile flammable liquids incidents, starting or tending an open fire was the activity reported most frequently, comprising 138 (21 percent) of the incidents. Both males and females in the 21-45 age group were injured most frequently from this activity. The males in the 13-20 and the 6-12 age groups also were injured frequently as a result of this activity. From a study of the case history reports for the male victims from these 3 age groups, there was an indication that this activity might be considered a play activity rather than a functional or utilitarian activity in some instances for the victims in the 6-12 and 13-20 age groups. Many of the males in the 6-12 age group were involved in experimenting with fires -- fires created to burn miscellaneous items from around the yard, fires started in old tree stumps, etc. The actions of the males in the 13-20 age group indicated there had been more planning for the fires with which they were involved. Many of the fires for this age group were incinerator fires. In contrast, males in the 21-45 age group were involved primarily with charcoal grill fires.

\footnotetext{
TSee appendix B for the classification system used ot obtain ignitioncausing activities.

10 The primary victim is defined as the person who was most involved in causality chain with the most important role being that of sustaining an injury. If there were no injuries reported, then the primary victim was the person whose actions initiated the fire or who was in some way directly involved.
} 
a. Volatile Flammable Liquids

\begin{tabular}{|c|c|c|c|c|c|c|c|}
\hline \multirow{2}{*}{ Activity ${ }^{*}$} & $0-5$ & $6-12$ & $13-20$ & $21-45$ & \multirow{2}{*}{$\begin{array}{r}46-65 \\
M \quad F\end{array}$} & \multirow{2}{*}{$M^{66+} F$} & \multirow{2}{*}{$\begin{array}{l}\text { Unknown } \\
M \quad F\end{array}$} \\
\hline & $M \quad F$ & M F & $M \quad F$ & $M \quad F$ & & & \\
\hline
\end{tabular}

Playing with matches or lighter

Playing with flammable liquid

Playing with flammable liquid and an ignition source

Starting/tending open fire

Disturbing open fire

Standing by open fire

Standing near ignition source

Standing near flammable liquid

Transferring flammable liquid

Carrying/transporting flammable liquid

Spilling/splashing flammable liquid

Knocking over/dropping flammable liquid

Refueling equipment

Cleaning/repairing equipment

Priming carburetor

Using machinery/ equipment

Using work tools

Using flammable liquid as cleaning agent

Using flammable liquid as exterminating agent

Using flammable liquid to ignite heat source

Using flammable liquid as adhesive

Using flammable liquid as paint

Using matches or lighter

Smoking

Driving/riding vehicle

Helping another person involved in incident

Suspected Arson

Assault/suicide

Total Known

$\begin{array}{llllllll}5 & 3 & 45 & 9 & 9 & 2 & 1\end{array}$

$\begin{array}{llllllllllllllll}5 & 1 & 23 & 3 & 29 & 5 & 34 & 8 & 16 & 5 & 5 & 3 & 1 & - & 138\end{array}$

- 53 - 1 - -1 - 1 - 1 -

$\begin{array}{lllllllllllll}- & 1 & 1 & 1 & 2 & - & - & - & - & 1\end{array}$

- -1 - 1 - 2 - 1 - - - -

\begin{tabular}{|c|c|c|c|c|c|c|c|c|c|c|c|c|}
\hline 7 & 1 & 2 & - & - & - & - & - & - & - & - & - & 11 \\
\hline 2 & 1 & 3 & - & - & - & - & - & - & - & - & - & 11 \\
\hline 5 & 9 & 9 & 2 & 1 & - & - & - & - & - & - & - & 74 \\
\hline 3 & 3 & 29 & 5 & 34 & 8 & 16 & 5 & 5 & 3 & 1 & - & 138 \\
\hline 3 & 1 & - & - & 1 & - & - & - & - & - & - & - & 6 \\
\hline 1 & 1 & 2 & - & 3 & - & 1 & - & - & - & - & 1 & 10 \\
\hline 1 & - & - & - & 2 & - & 1 & - & - & - & - & - & 4 \\
\hline 2 & - & 2 & - & 2 & 2 & - & - & - & 1 & - & - & 10 \\
\hline 3 & - & 3 & 1 & 2 & 1 & - & - & - & - & $1-$ & - & 10 \\
\hline 1 & - & 3 & - & - & - & 2 & - & - & 1 & - & - & 7 \\
\hline 7 & - & 12 & - & 11 & 6 & 5 & 1 & 1 & - & 1 & - & 48 \\
\hline 9 & 2 & 8 & 1 & 6 & 1 & 6 & 1 & - & - & - & - & 44 \\
\hline 2 & - & 1 & - & 4 & - & 4 & - & - & - & - & - & 12 \\
\hline - & 1 & 11 & 1 & 11 & - & 10 & - & 3 & - & - & - & 39 \\
\hline 1 & - & 8 & - & 16 & - & 7 & - & - & - & - & - & 33 \\
\hline 2 & 1 & 2 & 2 & 5 & 2 & 5 & - & 1 & 1 & - & - & 22 \\
\hline 1 & - & 6 & - & 11 & - & 3 & - & - & - & - & - & 21 \\
\hline 2 & 1 & 8 & 4 & 15 & 3 & 6 & 2 & 1 & 1 & 2 & - & 46 \\
\hline 1 & - & 3 & - & 3 & 1 & - & 1 & 1 & - & - & - & 10 \\
\hline
\end{tabular}

Unknown

-

$\begin{array}{llll}- & - & 1 & 1 \\ - & - & - & -\end{array}$

$\begin{array}{llll}- & - & - & - \\ - & - & - & 1\end{array}$

$\begin{array}{llllllll}- & - & 1 & - & - & - & - & - \\ - & - & - & - & 1 & - & - & 1 \\ - & - & 1 & - & 1 & 1 & 2 & -\end{array}$

1111

30

Total

$\begin{array}{llllllllllllll}27 & 16 & 118 & 23 & 127 & 20 & 157 & 31 & 75 & 15 & 18 & 13 & 4 & 1\end{array}$

The activities listed may not necessarily indicate the activity of the victim who represents the incident, but they do reflect the specific action which caused an ignition to occur. 
Table 9. Ignition-Causing Activities* by Age Groups and Sex (continued)

b. Grease and Other Less Volatile Flammable Liquids

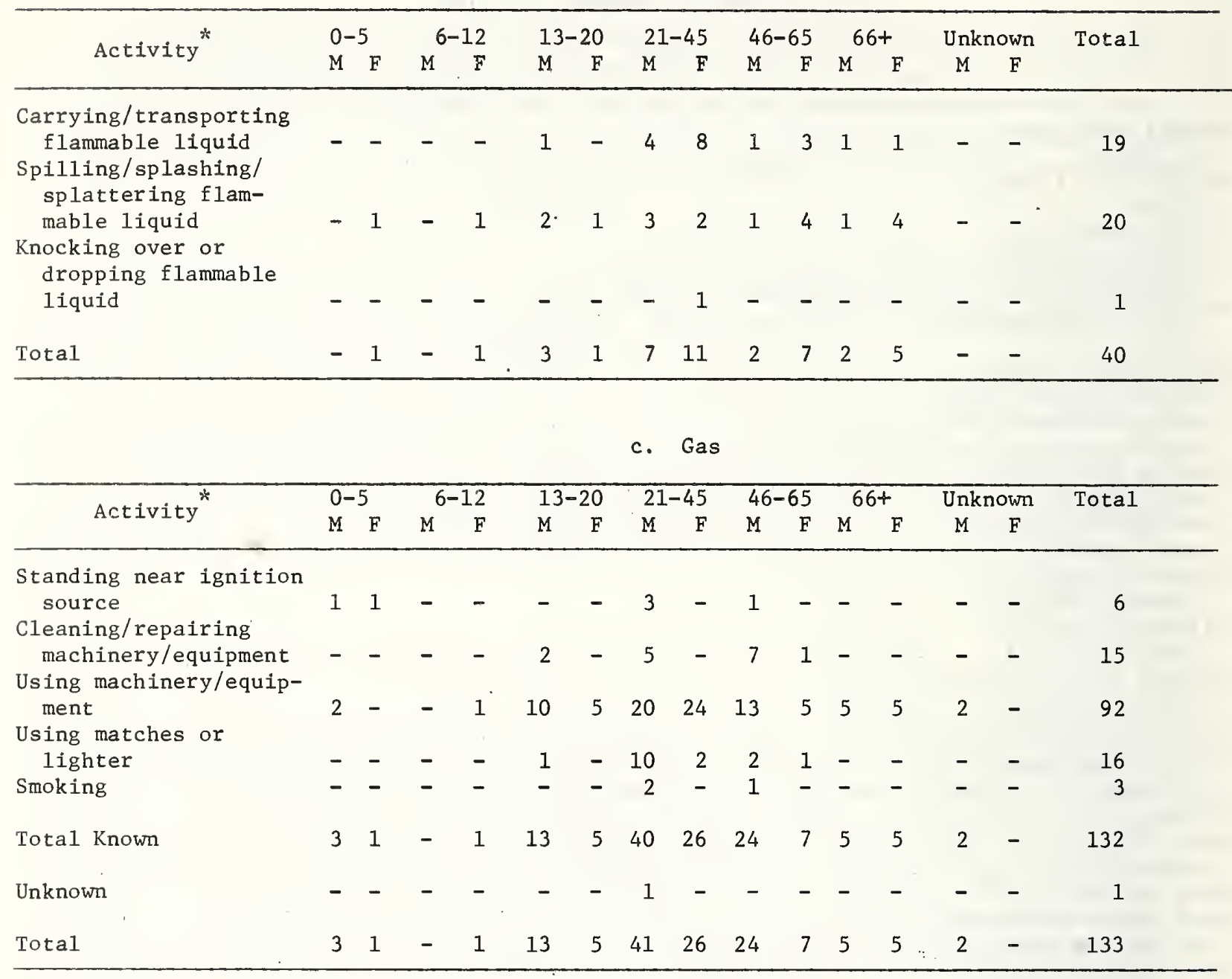

d. Dry Explosives

\begin{tabular}{|c|c|c|c|c|c|c|c|c|c|c|c|c|c|c|c|}
\hline \multirow{2}{*}{ Activity } & \multicolumn{2}{|c|}{$0-5$} & \multicolumn{2}{|c|}{$6-12$} & \multicolumn{2}{|c|}{$13-20$} & \multicolumn{2}{|c|}{$21-45$} & \multicolumn{2}{|c|}{$46-65$} & \multicolumn{2}{|c|}{$66+$} & \multicolumn{2}{|c|}{ Unknown } & \multirow[t]{2}{*}{ Total } \\
\hline & M & F & M & $\mathrm{F}$ & M & F & M & $\mathrm{F}$ & M & $\mathrm{F}$ & M & $\mathrm{F}$ & M & $\mathrm{F}$ & \\
\hline \multicolumn{16}{|l|}{$\begin{array}{l}\text { Playing with explosives } \\
\text { or ignition source }\end{array}$} \\
\hline or both & - & - & 2 & - & 6 & - & 1 & - & - & - & - & - & - & - & 9 \\
\hline $\begin{array}{l}\text { Standing near an } \\
\text { explosive or }\end{array}$ & & & & & & & & & & & & & & & \\
\hline ignition source & - & - & - & - & 1 & - & 1 & - & - & - & - & - & - & - & 2 \\
\hline $\begin{array}{l}\text { Cleaning/repair/using } \\
\text { machinery or equip- }\end{array}$ & & & & & & & & & & & & & & & \\
\hline ment & - & - & - & - & 1 & - & 1 & - & - & 1 & - & - & - & - & 3 \\
\hline Total & - & - & 2 & - & 8 & - & 3 & - & - & 1 & - & - & - & - & 14 \\
\hline
\end{tabular}

* The activities listed may not necessarily indicate the activity of the victim who represents the incident, but they do reflect the specific action which caused an ignition to occur. 
Playing with both an ignition source and a flammable liquid was the second most frequently reported activity representing 74 ( 11 percent) of the incidents. In many of the incidents this activity represented an open fire where matches and gasoline were involved generally. Both males and females in the 6-12 age group were injured most frequently from this activity.

The activities of spilling or splashing a flammable liquid, which occurred in 48 of the incidents; using a flammable liquid as a cleaning agent, which occurred in 46 of the incidents; and knocking over or dropping a container of flammable liquid, which occurred in 44 of the incidents; each represented 7 percent of these flammable liquid incidents.

Spilling or splashing a flammable liquid primarily involved both males and females in the 21-45 age group who attempted to lift or pour a flammable liquid in the presence of an ignition source. Children through the age of twelve, however, were injured more often than older age groups when they attempted to play with or use a container of flammable liquid and knocked or kicked it over in the presence of an ignition source. The ignition sources for all of these types of activities were generally hot water heaters, kitchen ranges, space heaters and furnaces.

Using a flammable liquid as a cleaning agent injured persons in the 21-45 age group most frequently. Victims in the 13-21 age group also were involved often with this activity. Using a flammable liquid as a cleaning agent or solvent, for the adults, generally involved the removal of tar, paint, tile, etc., from floors, counter-tops, paint brushes, etc., with a flammable liquid which was identified as gasoline in approximately half of the incidents. The fumes were subsequently ignited by a pilot light from a gas appliance. For the youth, this activity was generally defined as cleaning engine parts in a pan filled with a flammable liquid, usually identified as gasoline, in a basement or utility room where the pilot light from the water heater or furnace ignited the fumes.

Although it only represents 33 (5 percent) of the 645 volatile flammable liquid incidents, priming carburetors injured 16 males in the 21-45 age group which, for the males in this age group, is second in frequency only to the activity of starting or tending an open fire which injured. 34 males.

Victims in the 46-65 age group were injured most frequently from starting or tending an open fire -- often identified as a trash or leaf fire started in an open area. Males in this age group also were of ten involved in machinery and equipment related activities such as cleaning or repairing machinery and priming carburetors.

The elderly were injured most of ten from using matches or a lighter. Males in this age group were injured equally as of ten while starting or tending an open fire. 


\subsubsection{Grease and Other Less Volatile Flammable Liquids Category}

Spilling, splashing, or splattering a flammable liquid was the activity reported most frequently in the grease and other less volatile flammable liquids incidents, representing 20 (50 percent) of the incidents. Injuries resulting from this activity were sustained primarily by adults over the age of 20. Females represented 68 percent of. these adult victims. From a study of the case history reports, it was noted that the victims of this activity were attempting to extinguish a cooking grease or cooking oil fire either by removing the cooking utensil from the burner, spilling the hot grease or oil on themselves in the process, or by dousing the flames in the utensil with cold water from the tap, thus splashing or splattering the hot substance on themselves.

Carrying or transporting a flammable liquid represented 19 (48 percent) of these incidents with the injuries being sustained chiefly by adults (predominantly females) in the $21-45$ age group. Here victims were attempting to move a flaming or smoking cooking utensil from the range to the sink or outside and were injured as a direct result of transporting the utensil. These injuries generally occurred when the excited victim dropped the flaming utensil on themselves, jerked the utensil when the air currents created by carrying the utensil caused the flames or smoke to flare up, or when the surrounding objects (including garments on the victim) ignited from the flaming utensil as it was being carried.

\subsubsection{Gas Category}

For the 133 gas incidents, using machinery or equipment represented 92 (69 percent) of the incidents. Victims, mostly males, in the 21-45 age group followed by those in the 46-65 age group were injured most frequently. The victims were generally attempting to re-ignite extinguished pilot lights in furnaces, water heaters, gas ranges, etc., or otherwise trying to use equipment, such as ranges, when an explosion occurred. These victims were generally aware of a gas leakage and were in the process of tracing it to its source when an explosion occurred.

Sixteen (12 percent) of the gas incidents were the result of victims, mostly males, in the 21-45 age group, attempting to light a match or lighter in the presence of a gas leak. In many instances, the intent was to light a cigarette.

\subsubsection{Dry Explosives Category}

Playing with an explosive, an ignition source, or both represented 9 (64 percent) of the dry explosive incidents and involved males in the 13-20 age group most frequently. The explosives involved included gunpowder, black powder, rocket powder, and firecrackers. 
Cleaning, repairing, or using machinery or equipment represented another 3 (21 percent) of these incidents involving one male each from the 13-20 and 21-45 age groups and the female from the 46-65 age group. Accidents resulting from this activity occurred as the result of the victims cleaning out, lighting, or attempting to use a coal furnace. No victims in the youngest and oldest age groups were involved in the dry explosives incidents.

\subsection{Known First-to-Ignite Fabric Items}

\subsubsection{Ignition Sources}

In table 10, the 466 fabric items which were known to have ignited first are tabulated for all of the victims reported in these 832 incidents 11 by ignition sources for each intermediary material category. These fabric items are grouped by outer wear, street wear, underwear, sleepwear, accessories and other miscellaneous garments, interior furnishings, and miscellaneous fabrics. Since it is postulated that fabrics contaminated with flammable liquids exhibit altered flammability characteristics, the fabric groups represented in both of the flammable liquids tables have been partitioned to reflect the contamination status.

\subsubsection{Volatile Flamable Liquids Category}

For the 645 volatile flammable liquids incidents, 378 fabric items were known to have been first-to-ignite items. Street wear followed by underwear and outer wear were ignited first most frequently.

Street wear (which, for these incidents, consisted of pants/slacks, shorts, dresses, a gown, shirts/blouses, sweatshirts, sweaters, overalls/ coveralls, and a vest) represented 276 (73 percent) of the volatile flammable liquids fabric ignitions. Shirts/blouses followed by pants/ slacks were the most frequent items reported, representing 135 ( 49 percent) and 94 (34 percent) of the street wear garments, respectively.

Underwear (which consisted of undershirts, underpants, socks, and stockings/leotards) represented 47 (12 percent) of the ignitions. Undershirts were most prevalent, representing 32 (68 percent) of the underwear items.

Outer wear (coats, jackets, and a hat) represented 25 ( 9 percent) of the ignitions. Jackets were the most frequently reported item, representing 21 of the 25 outer wear items known to have ignited first.

${ }^{11}$ In incidents where more than one victim was reported, known first-toignite garment items were reported on a per victim basis. 


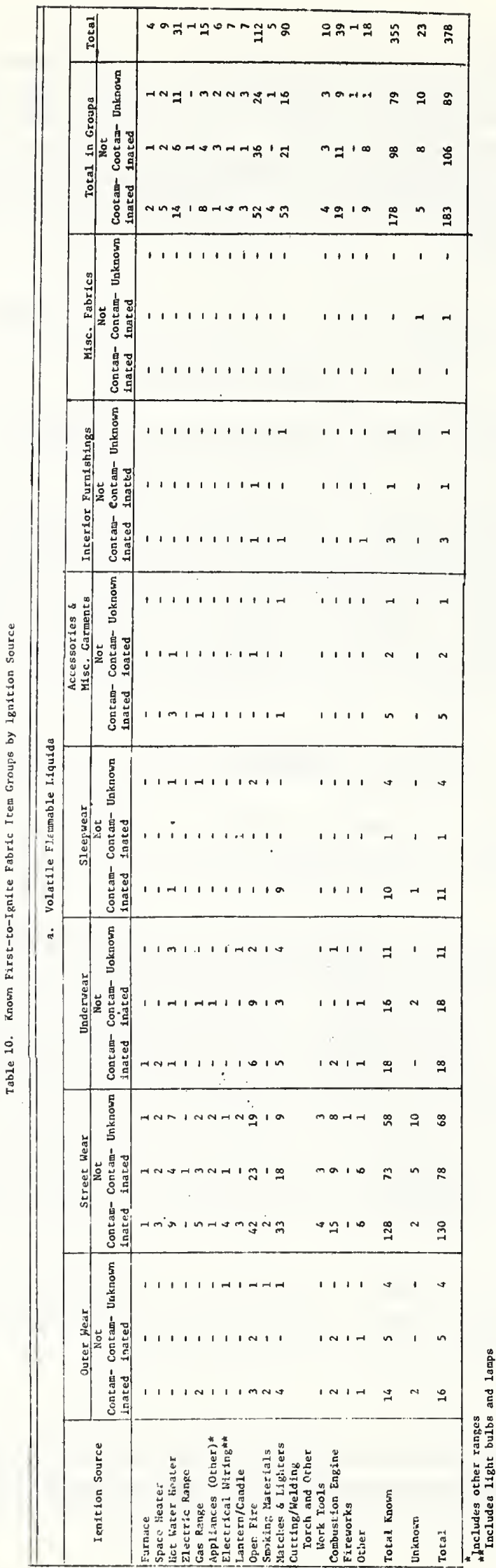




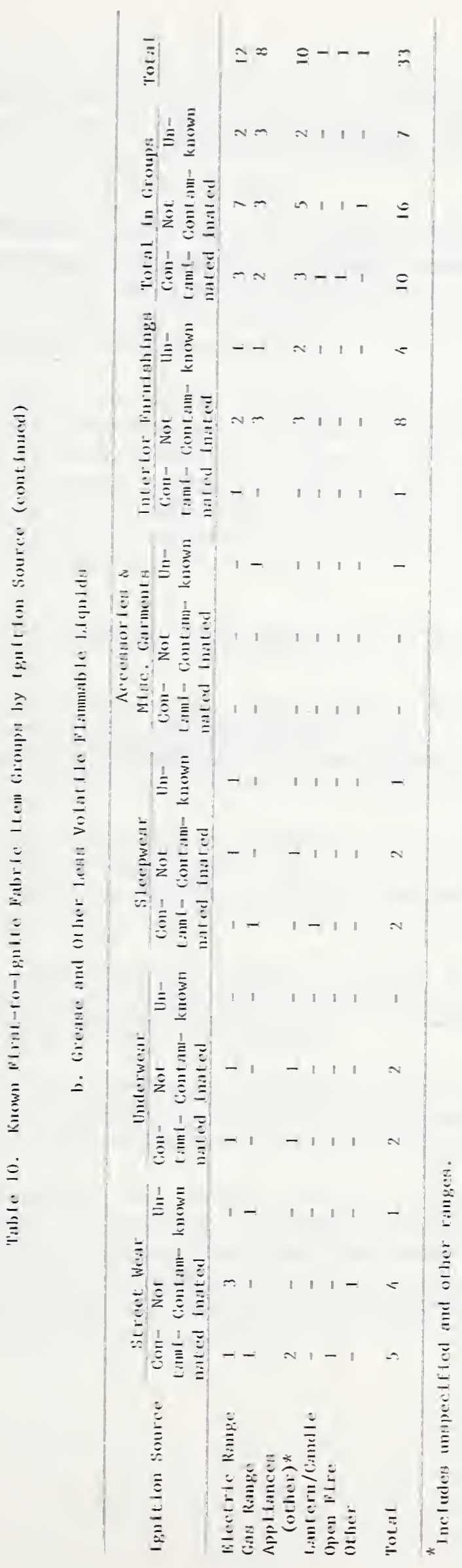


Table 10. (continued)

c. Gas

\begin{tabular}{|c|c|c|c|c|c|c|}
\hline Ignition Source & Outer Wear & Street Wear & Underwear & Sleepwear & $\begin{array}{c}\text { Interior } \\
\text { Furnishings } \\
\end{array}$ & Total \\
\hline Furnace & - & 3 & 1 & 1 & - & 5 \\
\hline Space Heater & 2 & 1 & 1 & - & 2 & 6 \\
\hline Hot Water Heater & - & 1 & - & - & - & 1 \\
\hline Appliances (Other) & - & 1 & - & - & - & 1 \\
\hline Electric Wiring & - & 1 & - & - & - & 1 \\
\hline Open Fire & - & 1 & - & - & - & 1 \\
\hline Matches or Lighters & - & 19 & 2 & 3 & - & 24 \\
\hline Other & - & 2 & 1 & 1 & - & 4 \\
\hline Total known & 2 & 29 & 5 & 5 & 2 & 43 \\
\hline Unknown & - & 3 & - & - & - & 3 \\
\hline Total & 2 & 32 & 5 & 5 & 2 & 46 \\
\hline
\end{tabular}

d. Dry Explosives

\begin{tabular}{lcccc}
\hline Ignition Source & Street Wear & Underwear & Sleepwear & Total \\
\hline Furnace & - & - & 1 & 1 \\
Matches \& Lighters & 1 & 2 & - & 3 \\
Other & 1 & 1 & - & 2 \\
Total known & 2 & 3 & - & 6 \\
Unknown & 3 & - & 1 & 9 \\
Total & 5 & 3 & & 9 \\
\hline
\end{tabular}


For the volatile flammable liquids incidents, sleepwear included pajamas, nightgowns, and robes/housecoats; accessories and miscellaneous garments included an apron and shoes; interior furnishings included a pair of draperies, a carpet or rug, and several upholstered items; and miscellaneous fabrics included a tent.

of the 378 fabric items for the category, fabrics contaminated with a flammable liquid comprised 183 (48 percent), fabrics not contaminated represented 106 ( 28 percent), and the status for the 89 (24 percent) remaining fabrics was unknown. Seventy-one percent of the contaminated fabrics were from the street wear group.

Fifty-two percent of all the fabrics were ignited by open fires, and matches and lighters which were identified as the major ignition sources for the volatile flammable liquids category. Fifty-seven percent of the contaminated fabrics were ignited by these ignition sources. Appliances (furnaces, space heaters, water heaters, ranges, etc.) and combustion engines were the ignition sources for 16 percent and 10 percent, respectively, of these contaminated fabrics.

\subsubsection{Grease and Other Less Volatile Flammable Liquids Category}

For the 40 grease and other less volatile flammable liquids incidents, 33 fabric items were known to have ignited first. Interior furnishings followed by street wear were the most frequently first-to-ignite groups of fabric items.

Interior furnishings (which consisted of a bedspread, curtains/draperies, a carpet/rug, a tablecloth, and a pot holder) represented 13 (39 percent) of the ignitions for the category. Draperies/curtains were rereported most often, comprising 9 of the 13 items in the group.

Street wear (pants/slacks, dresses, skirts, shirts/blouses, and sweatshirts) represented 10 (30 percent) of the ignitions. Shirts/blouses comprised 4 of the 10 street wear items.

Sleepwear included pajamas, nightgowns, and robes/housecoats; underwear included slips, socks, and stockings/leotards; and an apron was the only fabric item reported for Accessories and Miscellaneous Garments.

Ten (30 percent) of the fabric items for this intermediary material category were known to have been contaminated with a flammable liquid, 16 (49 percent) were not contaminated, and the status of 7 (21 percent) was not known. Fifty percent of the contaminated fabric items were in the street wear group. Only one item in the furnishings group, the pot holder, was reported to have been contaminated. 
Kitchen ranges were the ignition source for 91 percent of all of the fabric ignitions. This included all of the 9 curtain/drapery ignitions and 3 of the 4 shirt/blouse ignitions from the major fabric groups. Kitchen ranges were the ignition source for 80 percent of the contaminated fabrics.

\subsubsection{Gas Category}

For the 133 gas incidents, 46 fabric items were known to have ignited first. Street wear (pants/slacks, dresses, shirts/blouses, sweaters, and culottes) was the most frequently reported group of fabric items, representing 32 ( 70 percent) of the items for the category. Shirts and blouses represented 19 of the 32 garments.

Sleepwear (pajamas, nightgowns, and robes/housecoats) and underwear (undershirts, underpants, and stockings/leotards) were the next most frequently reported groups, each having 5 -garment items. Robes and housecoats represented 3 of the 5 sleepwear items and undershirts represented 2 of the 5 underwear items.

Jackets and carpets were the only items reported for the outer wear and the interior furnishings groups, respectively.

Matches and lighters were the ignition source for 24 (52 percent) of the fabric ignitions for the gas category: 91 percent of the ignitions in the street wear group and half of those in the sleepwear and underwear group were the result of matches and lighters. Although not contributing substantially to any one fabric group listed, space heaters and furnaces ranked second to matches and lighters as an ignition source, representing 6 (13 percent) and 5 (11 percent), respectively, of the ignition sources for this intermediary material category.

\subsubsection{Dry Explosives Category}

For the 14 dry explosives incidents, 9 fabric items were reported as being first-to-ignite. Street wear predominated with 1 pants/slacks, 3 shirts/blouses, and a sweatshirt. Underwear was represented with 3 undershirts, and sleepwear followed with one robe. Matches and lighters were the major ignition sources.

\subsubsection{Age Groups and Sex}

The known first-to-ignite fabric item groups discussed in table 10 are displayed again by age groups for each sex in table 11. 


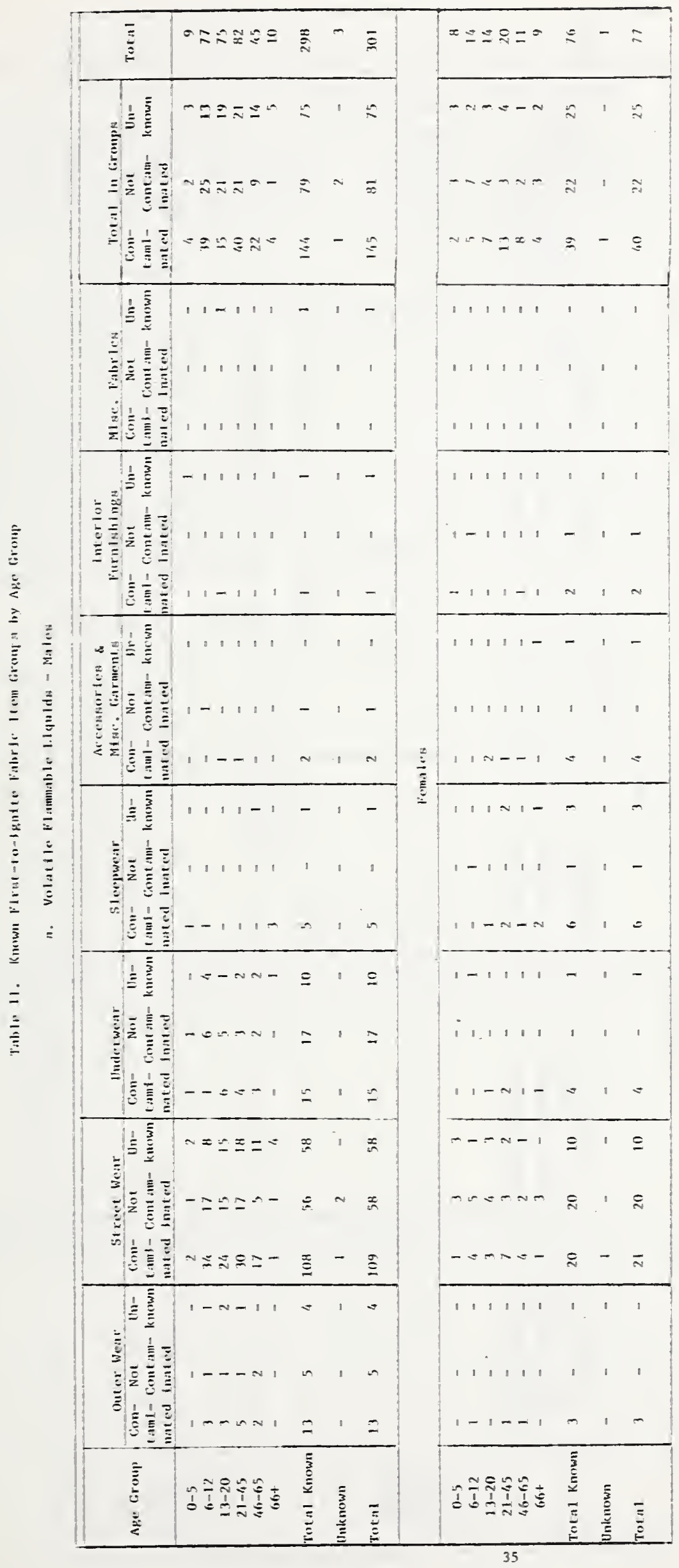




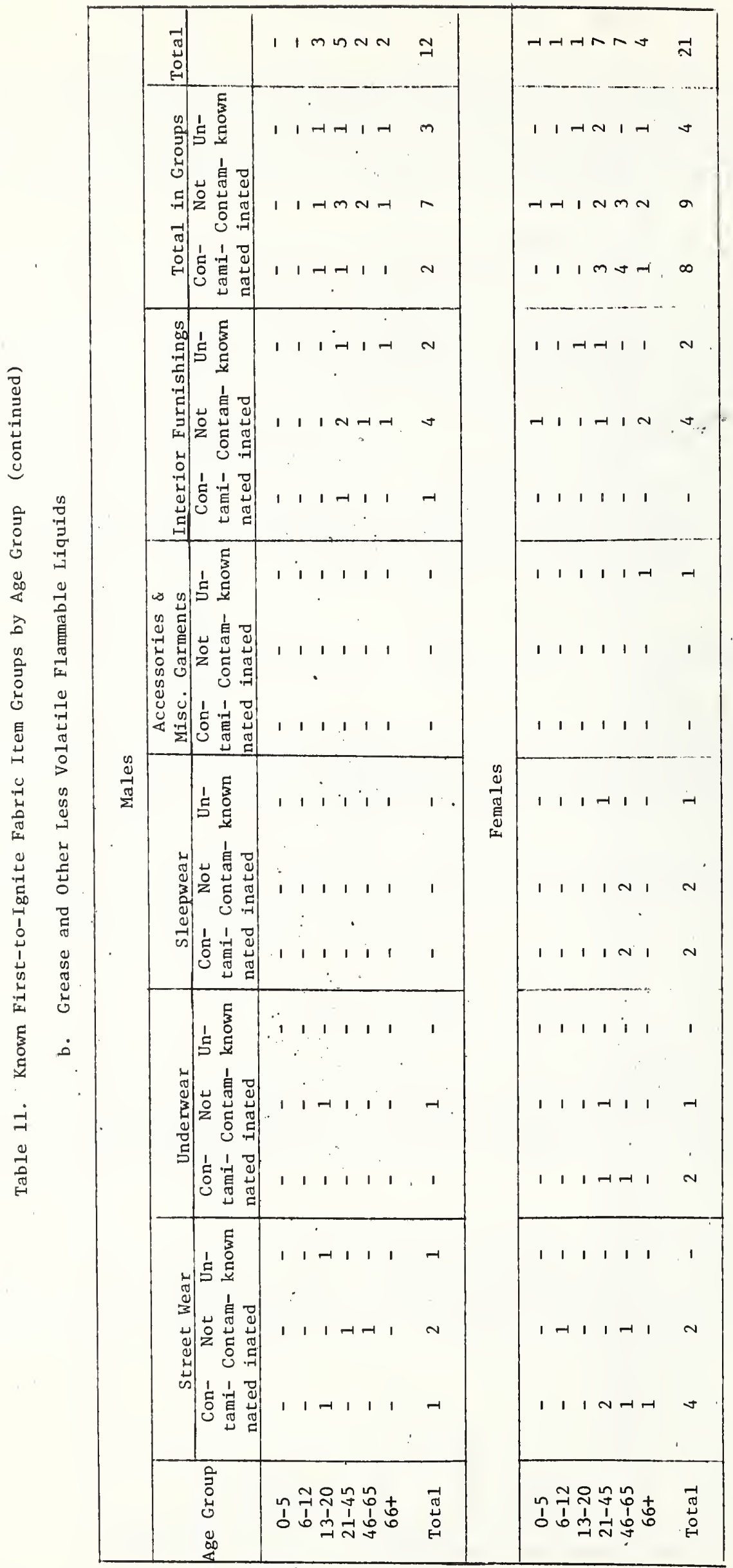


Table 11. Known First-to-Ignite Fabric Item Groups by Age Group (continued)

c. Gas - Males

\begin{tabular}{|c|c|c|c|c|c|c|}
\hline Age Group & Guter Wear & Street Wear & Underwear & Sleepwear & $\begin{array}{l}\text { Interior } \\
\text { Furnishings }\end{array}$ & Total \\
\hline $0-5$ & - & - & - & - & $I$ & 1 \\
\hline $6-12$ & - & - & - & - & - & - \\
\hline $13-20$ & - & 5 & 1 & - & - & 6 \\
\hline $21-45$ & 1 & 7 & 2 & - & - & 10 \\
\hline $46-65$ & 1 & 6 & - & 1 & - & 8 \\
\hline $66+$ & - & 2 & - & - & - & 2 \\
\hline Total known & 2 & 20 & 3 & 1 & 1 & 27 \\
\hline Unknown & - & 1 & - & - & - & 1 \\
\hline Total & 2 & 21 & 3 & 1 & 1 & 28 \\
\hline
\end{tabular}

Females

\begin{tabular}{ccccccc}
\hline Age Group & Outer Wear & Street Wear & Underwear & Sleepwear & $\begin{array}{c}\text { Interior } \\
\text { Furnishings }\end{array}$ & Total \\
\hline $0-5$ & - & - & - & - & 1 & 1 \\
$6-12$ & - & - & - & 1 & - & 1 \\
$13-20$ & - & 8 & 1 & - & - & 1 \\
$21-45$ & - & 2 & - & 1 & - & 3 \\
$46-65$ & - & 1 & - & - & - & 1 \\
$66+$ & - & 11 & 2 & 4 & 1 & 18 \\
\hline
\end{tabular}

d. Dry Explosives - Males

\begin{tabular}{ccccc}
\hline Age Group & Street Wear & Underwear & Sleepwear & Total \\
\hline $0-5$ & - & - & - & - \\
$6-12$ & - & 1 & - & 1 \\
$13-20$ & 3 & 2 & - & 5 \\
$21-45$ & 2 & - & 1 & 2 \\
$46-65$ & - & - & - & 1 \\
$66+$ & - & 3 & 1 & 9 \\
Total & 5 & &
\end{tabular}




\subsubsection{Volatile Flammable Liquids Category}

Males represented 80 percent of the 378 victims involved with firstto-ignite fabric items in the volatile flammable liquids incidents. For both sexes, street wear was reported most frequently as being first-toignite. This was followed by underwear and outer wear for the males and sleepwear for the females.

Males in the 6-45 age range were reported most frequently in the 8 groups of garment types mentioned above. These victims were frequently involved with starting or adding a flammable liquid to an existing fire. In addition, males in the 6-12 age group were often reported to be playing with a flammable liquid and an ignition source, and males in the $21-45$ age group were also frequently involved with machinery and equipment related activities. In general, street wear would be considered the most logical dress for these types of activities and slacks and shirts, in particular, probably would be expected to be involved most often, as was indicated in table 10. The frequent involvement of underwear (primarily undershirts) and outer wear (primarily jackets), in these activities may reflect seasonal variations.

Females in the 6-45 age range were reported most frequently in the street wear group of fabrics with approximately 38 percent of these females being in the 21-45 age group. These females were of ten involved with starting or tending an open fire. In addition, females in the 6-12 age group were involved frequently with playing with a flammable liquid and an ignition source. Blouses, dresses, and slacks were the most frequent items reported for these age groups in the street wear group.

Females in the 21-45 and 66+ age groups were represented of ten in the sleepwear group of fabric items where the garments reported frequently were robes and nightgowns. For the elderly, the activity with which they were involved most often was using matches or lighters, generally for smoking purposes.

Approximately half of the garment items in these 4 fabric groups for both sexes were contaminated with a flammable liquid at ignition with no one age group predominating.

\subsubsection{Grease and Other Less Volatile Flammable Liquids Category}

Females dominated the grease and other less volatile flammable liquids incidents, almost 2 to 1 over males. For both sexes, interior furnishings were reported most frequently as igniting first. In addition, females were involved often with street wear and sleepwear.

Females in the 21-65 age range were the most frequent victims of incidents for this intermediary material category. Females in the 21-45 age group were involved most often with interior furnishings (primarily 
draperies or curtains) followed by street wear (mostly dresses). Females in the 46-65 age group were involved most often with street wear (mostly dresses) and sleepwear (primarily nightgowns).

Males from the age of 13 on were involved in this intermediary material category, but males in the 21-45 age group were represented most frequently. This age group of males was represented most frequently in the interior furnishings group where, again, draperies or curtains were the items reported as igniting first most often.

Most of the interior furnishings, as was indicated, were curtains or draperies which ignited when the victims attempted to extinguish or remove a flaming or smoking cooking utensil from the range. Although females in the 21-65 age group were injured often in these incidents while wearing street wear, females, predominantly in the 45-65 age group, were injured while wearing sleepwear garments. A trend has been noted previously in the FFACTS datal2 of older women being injured frequently as the result of wearing long, loose-fitting sleepwear while preparing food on the kitchen range.

\subsubsection{Gas Category}

Males comprised 61 percent of the 46 victims representing first-toignite fabric items in the gas incidents. Street wear was reported most frequently for both sexes as would be expected because of the nature of the activities involved -- primarily attempting to ignite the pilot light on a gas appliance.

Sixty-two percent of the street wear ignitions for the males occurred in the 21-65 age range. Shirts represented the majority of these street wear items. Males in this age range were the only victims represented in the outer wear group (jackets) and constituted the major portion of the victims in the underwear group (undershirts).

Ninety-one percent of the street wear ignitions for the females occurred in the 21-65 age range with the majority of the garment items being sweaters and dresses. Females in this age range were represented most frequently in the sleepwear group where robes/housecoats predominated.

\subsubsection{Dry Explosives Category}

Eight males and one female were represented in the dry explosives incidents. Street wear (primarily shirts) was represented most frequently followed by underwear (undershirts). Males in the 13-20 age group, which represent the majority of the males for the category were involved most frequently in both groups of garment items. As the incidents in this category involved explosions which were considered generally to have been caused by play-related activities, street wear would be expected to dominate the garment items involved. The underwear (undershirt) involvement may reflect the season.

${ }^{12}$ Vickers, A. K., Kitchen Ranges in Fabric Fires, Nat. Bur. Stand. (U.S.), NBS Technical Note 817 (Apr. 1974). 


\subsection{Severity of Burn Injury}

In table 12, the total body area burned is presented by age groups and sex for each intermediary material category. For the two flammable liquids categories, this information is presented by flammable liquid contaminated and non-contaminated fabric groups.

\subsubsection{Volatile Flammable Liquids Category}

Three hundred (45 percent) of the 668 victims reported for the volatile flammable liquids category were injured while involved with fabrics known to be contaminated with a flammable liquid at ignition. One hundred eighty-six (28 percent) of the victims in this category sustained injuries while involved with fabrics known not to be contaminated with a flammable liquid. The status of the fabrics with which the remaining 182 (27 percent) victims were involved was uncertain; therefore, these victims were omitted from the table.

In the contaminated fabrics group, 168 (56 percent) of the victims sustained burn injuries covering less than 21 percent of their bodies; 115 of these victims sustained burn injuries covering only 1-10 percent of their bodies. Only 6 percent of the victims sustained burn injuries covering 61 percent or more of their bodies. In the non-contaminated fabric group, 101 (54 percent) of the victims sustained burn injuries covering less than 21 percent of their bodies. Similarly, 6 percent of the victims in this fabric group sustained burn injuries covering 61 percent or more of their bodies. The distribution of injuries throughout the age and sex groups in these tables shows no indication that fabric contamination substantially increased the severity of the burn injuries received.

\subsubsection{Grease and Other Less Volatile Flammable Liquids Category}

Twelve ( 30 percent) of the 40 victims reported for the grease and other less volatile flammable liquids category were injured while involved with fabrics contaminated with a flammable liquid. Sixteen (40 percent) of the victims were involved with non-contaminated fabrics at the time of the ignition. The majority of the victims from both of these tables sustained burn injuries covering 10 percent or less of their bodies. only 2 victims sustained burn injuries covering 61 percent or more of their bodies; both were from the non-contaminated fabric group. There is no indication in these data that fabric contamination with a flammable liquid correlates with the severity of the burn injuries sustained.

\subsubsection{Gas Category}

Of the 141 victims represented in the gas incidents, 71 (50 percent) sustained burn injuries covering less than 21 percent of their bodies; 49 of these victims received burn injuries covering only 1-10 percent of 
a. Volatile Flammable Liquids" - Contaminated Fabrics

\begin{tabular}{|c|c|c|c|c|c|c|c|c|c|c|c|c|c|c|c|}
\hline \multirow{2}{*}{$\begin{array}{l}\text { Percent of } \\
\text { Body Burmed }\end{array}$} & \multicolumn{2}{|c|}{$0-5$} & \multicolumn{2}{|c|}{$6-12$} & \multicolumn{2}{|c|}{$13-20$} & \multicolumn{2}{|c|}{$21-45$} & \multicolumn{2}{|c|}{$46-65$} & \multicolumn{2}{|c|}{$66+$} & \multicolumn{2}{|c|}{ Unknown } & \multirow[b]{2}{*}{ Total } \\
\hline & $M$ & $\mathrm{E}$ & M & $\mathrm{F}$ & M & $\mathrm{F}$ & M & E & M & $\mathrm{F}$ & M & $\mathrm{F}$ & M & F & \\
\hline $1-10 \%$ & 2 & 2 & 31 & 2 & 29 & 2 & 24 & 5 & 14 & 2 & - & 1 & 1 & - & 115 \\
\hline $11-20 \%$ & 1 & - & 12 & 1 & 12 & 2 & 12 & 3 & 6 & 2 & 1 & 1 & - & - & 53 \\
\hline $21-30 \%$ & 2 & 1 & 7 & 3 & 8 & 1 & 14 & 2 & 4 & 2 & 5 & - & - & - & 49 \\
\hline $31-60 \%$ & 5 & 1 & 8 & 3 & 8 & 3 & 11 & 5 & 2 & 2 & 1 & - & - & - & 49 \\
\hline $61+\%$ & 1 & 1 & 1 & - & 2 & 1 & 4 & - & 6 & - & 2 & 1 & - & - & 19 \\
\hline Total known & 11 & 5 & 59 & 9 & 59 & 9 & 65 & 15 & 32 & 8 & 9 & 3 & 1 & - & 285 \\
\hline Unknown & 1 & - & 4 & - & 2 & 1 & 5 & - & 1 & - & - & - & - & 1 & 15 \\
\hline Total & 12 & 5 & 63 & 9 & 61 & 10 & 70 & 15 & 33 & 8 & 9 & 3 & 1 & 1 & 300 \\
\hline
\end{tabular}

Non-Contaminated Fabrics

\begin{tabular}{|c|c|c|c|c|c|c|c|c|c|c|c|c|c|c|c|}
\hline \multirow{2}{*}{$\begin{array}{l}\text { Percent of } \\
\text { Body Burned }\end{array}$} & \multicolumn{2}{|c|}{$0-5$} & \multicolumn{2}{|c|}{$6-12$} & \multicolumn{2}{|c|}{$13-20$} & \multicolumn{2}{|c|}{$21-45$} & \multicolumn{2}{|c|}{$46-65$} & \multicolumn{2}{|c|}{$66+$} & \multicolumn{2}{|c|}{ Unknown } & \multirow[b]{2}{*}{ Total } \\
\hline & M & $\mathrm{F}$ & M & $\mathrm{F}$ & M & $\mathrm{F}$ & M & $\mathrm{F}$ & M & F & M & $\mathrm{F}$ & M & $\mathrm{F}$ & \\
\hline $1-10 \%$ & 2 & - & 5 & 2 & 15 & 2 & 10 & 3 & 6 & 2 & - & 3 & - & - & 50 \\
\hline $11-20 \%$ & - & - & 13 & 4 & 9 & 2 & 13 & 2 & 4 & 1 & 1 & 1 & 1 & - & 51 \\
\hline $21-30 \%$ & - & - & 9 & 3 & 6 & 1 & 8 & - & 1 & - & - & - & - & - & 28 \\
\hline $31-60 \%$ & 2 & 2 & 4 & - & 7 & - & 13 & 1 & 4 & 1 & - & 1 & - & - & 35 \\
\hline $61+\%$ & - & 3 & 1 & - & 2 & - & 5 & - & - & 1 & - & - & - & - & 12 \\
\hline Total Known & 4 & 5 & 32 & 9 & 39 & 5 & 49 & 6 & 15 & 5 & 1 & 5 & 1 & - & 176 \\
\hline Unknown & - & 1 & 1 & - & - & - & 4 & 1 & - & - & - & 2 & 1 & - & 10 \\
\hline Total & 4 & 6 & 33 & 9 & 39 & 5 & 53 & 7 & 15 & 5 & 1 & 7 & 2 & - & 186 \\
\hline
\end{tabular}

"Tlie status of the fabrics with which 182 of the victims for the volatile flammable liquids were involved was uncertain; hence these victims are omitted from the table.

** Total body area burned includes partial and full thickness burns, where a partial thickness burn is equivalent to a first or second degree burn and a full thickness burn is equivalent to a third degree burn. 
Table 12. Total Body Area Burned hy Age Groups and Sex (Continued)

b. Cirease and Other Less Volatile Flammable Liquids"

\begin{tabular}{|c|c|c|c|c|c|c|c|c|c|c|c|c|c|c|c|}
\hline \multirow{2}{*}{$\begin{array}{l}\text { Percent of } \\
\text { Body Burned }\end{array}$} & \multicolumn{2}{|c|}{$0-5$} & \multicolumn{2}{|c|}{$6-12$} & \multicolumn{2}{|c|}{$13-20$} & \multicolumn{2}{|c|}{$21-45$} & \multicolumn{2}{|c|}{$46-65$} & \multicolumn{2}{|c|}{$66+$} & \multicolumn{2}{|c|}{ Unknown } & \multirow[b]{2}{*}{ Total } \\
\hline & M & $\mathrm{F}$ & M & $\mathrm{F}$ & M & $\mathrm{F}$ & $M$ & $F$ & $\mathrm{M}$ & F & $\mathrm{M}$ & $\mathrm{F}$ & $\mathrm{M}$ & $\mathrm{F}$ & \\
\hline $1-10 \%$ & - & - & - & - & - & - & 2 & 2 & - & 1 & - & - & - & - & 5 \\
\hline $11-20 \%$ & - & - & - & - & 1 & - & - & 2 & - & - & - & - & - & - & 3 \\
\hline $21-30 \%$ & - & - & - & - & - & - & - & - & - & 2 & - & - & - & - & 2 \\
\hline $31-60 \%$ & - & - & - & - & - & - & - & - & - & 1 & - & 1 & - & - & 2 \\
\hline $61+\%$ & - & - & - & - & - & - & - & - & - & - & - & - & - & - & 0 \\
\hline Unknown & - & - & - & - & - & - & - & - & - & - & - & - & - & - & - \\
\hline Total & - & - & - & - & 1 & - & 2 & 4 & - & 4 & - & 1 & - & - & 12 \\
\hline
\end{tabular}

Non-Contaminated Fabrics

\begin{tabular}{|c|c|c|c|c|c|c|c|c|c|c|c|c|c|c|c|}
\hline \multirow{2}{*}{$\begin{array}{l}\text { Percent of } \\
\text { Body Burned }\end{array}$} & \multicolumn{2}{|c|}{$0-5$} & \multicolumn{2}{|c|}{$6-12$} & \multicolumn{2}{|c|}{$13-20$} & \multicolumn{2}{|c|}{$21-45$} & \multicolumn{2}{|c|}{$46-65$} & \multicolumn{2}{|c|}{$66+$} & \multicolumn{2}{|c|}{ Unknown } & \multirow[b]{2}{*}{ Total } \\
\hline & M & $\mathrm{F}$ & M & $\mathrm{F}$ & M & $F$ & M & $\mathrm{F}$ & M & $\mathrm{F}$ & $\mathrm{M}$ & $\mathrm{F}$ & M & $\mathrm{F}$ & \\
\hline $1-10 \%$ & - & - & - & - & 1 & - & 1 & 2 & - & 1 & - & 2 & - & - & 7 \\
\hline $11-20 \%$ & - & - & - & - & - & - & 1 & - & - & - & - & - & - & - & 1 \\
\hline $21-30 \%$ & - & - & - & - & - & - & - & - & - & - & - & - & - & - & 0 \\
\hline $31-60 \%$ & - & - & - & - & - & - & - & 1 & - & 2 & - & - & - & - & 3 \\
\hline $61+\%$ & - & - & - & 1 & - & - & - & - & - & - & - & 1 & - & - & 2 \\
\hline Unknown & - & '1 & - & - & - & - & - & - & 1 & - & 1 & - & - & - & 3 \\
\hline Tota 1 & - & 1 & - & I & 1 & - & 2 & 3 & 1 & 3 & 1 & 3 & - & - & 16 \\
\hline
\end{tabular}

c. Gas

\begin{tabular}{|c|c|c|c|c|c|c|c|c|c|c|c|c|c|c|c|}
\hline \multirow{2}{*}{$\begin{array}{l}\text { Percent of } \\
\text { Body Burned }\end{array}$} & \multicolumn{2}{|c|}{$0-5$} & \multicolumn{2}{|c|}{$6-12$} & \multicolumn{2}{|c|}{$13-20$} & \multicolumn{2}{|c|}{$21-45$} & \multicolumn{2}{|c|}{$46-65$} & \multicolumn{2}{|c|}{$.66+$} & \multicolumn{2}{|c|}{ Unknown } & \multirow[b]{2}{*}{ Tota 1} \\
\hline & M & $\mathrm{F}$ & M & $\mathrm{F}$ & $\mathrm{M}$ & $\mathrm{F}$ & $\mathrm{M}$ & $\mathrm{F}$ & $\mathrm{M}$ & $F$ & $\mathrm{M}$ & $\mathrm{F}$ & M & $\mathrm{F}$ & \\
\hline $1-10 \%$ & - & - & - & 1 & 5 & 2 & 11 & 17 & 8 & - & 2 & 2 & 1 & - & 49 \\
\hline $21-30 \%$ & - & - & - & - & 3 & - & 4 & 1 & 4 & 5 & - & - & - & - & 17 \\
\hline $31-60 \%$ & 3 & - & - & - & 3 & - & 16 & 3 & 3 & - & 2 & 2 & - & - & 32 \\
\hline $61+\%$ & - & 1 & - & - & 1 & 1 & 6 & - & - & - & - & - & - & - & 9 \\
\hline Unknown & - & - & - & - & 2 & $I$ & 4 & 2 & 3 & - & - & - & - & - & 12 \\
\hline Total & 3 & 1 & - & 1 & 14 & 5 & 45 & 27 & 26 & 7 & 5 & 5 & 2 & - & 141 \\
\hline
\end{tabular}

*The status of the fabrics with which 12 of the victims for the grease and other less volatile flammable liquids were involved was uncertain; therefore these victims are omitted from the table.

* Total body area burned includes partial and full thickness burns, where a partial thickness burn is equivalent to a first or second degree burn and a full thickness burn is equivalent to a third degree burn. 
Table 12. Total Body Area Burned by Age Groups and Sex (Cont1nued)

d. Dry Explosives

\begin{tabular}{|c|c|c|c|c|c|c|c|c|c|c|c|c|c|c|c|}
\hline \multirow{2}{*}{$\begin{array}{l}\text { Percent of } \\
\text { Body Burned } \% *\end{array}$} & \multicolumn{2}{|c|}{$0-5$} & \multicolumn{2}{|c|}{$6-12$} & \multicolumn{2}{|c|}{$13-20$} & \multicolumn{2}{|c|}{$21-45$} & \multicolumn{2}{|c|}{$46-65$} & \multicolumn{2}{|c|}{$66+$} & \multicolumn{2}{|c|}{ Unknown } & \multirow[b]{2}{*}{ Total } \\
\hline & M & F & M & $F$ & M & F & M & $F$ & M & $\mathrm{F}$ & $\mathrm{M}$ & $\mathrm{F}$ & M & $\mathrm{F}$ & \\
\hline $1-10 \%$ & - & - & - & - & 3 & - & 1 & - & -. & - & - & - & - & - & 4 \\
\hline $11-20 \%$ & - & - & 1 & - & 1 & - & 1 & - & - & - & - & - & - & - & 3 \\
\hline $21-30 \%$ & - & - & 1 & - & - & - & - & - & - & - & - & - & - & - & 1 \\
\hline $31-60 \%$ & - & - & - & - & 3 & - & 1 & - & - & $1^{+}$ & - & - & - & - & 5 \\
\hline $61+\%$ & - & - & - & - & - & - & - & - & - & - & - & - & - & - & - \\
\hline Total Known & - & - & 2 & - & 7 & - & 3 & - & - & 1 & - & - & - & - & 13 \\
\hline Unknown & - & - & - & - & 1 & - & - & - & - & - & - & - & - & - & 1 \\
\hline Total & - & - & 2 & - & 8 & - & 3 & - & - & 1 & - & - & - & - & 14 \\
\hline
\end{tabular}


their bodies. Only 6 percent of the victims in this category sustained burn injuries covering 61 percent or more of their bodies, mostly young adults in the 21-45 age group. Thirty-two (23 percent) of the victims, however, did receive burn injuries covering 31-60 percent of their bodies.

\subsubsection{Dry Explosives Category}

Five of the 13 victims in this category of intermediary materials (36 percent), sustained burn injuries covering 31-60 percent of their bodies. Three of these 5 victims were males in the 13-20 age group. The one female in the dry explosives incidents, who was the only victim in the 4665 age group, also sustained burn injuries in the 31-60 percent range. Most of the remaining victims received burn injuries that were much less severe. None of the victims for the dry explosives incidents sustained burn injuries covering 61 percent of more of their bodies.

\subsection{Injury Disposition}

In table 13, injury disposition for the 863 victims of the 832 incidents studied are shown by intermediary material categories. The greatest percentage of the victims for all categories were hospitalized for treatment of their burn injuries. Since accident investigations are generally made immediately following the accidents without any follow-up reports, it is not known what fraction of these hospitalized victims survived. However, entries have been made for those victims who were reported to have been hospitalized and subsequently died or were dead upon arrival at a hospital.

\subsubsection{Volatile Flammable Liquids Category}

Of the 668 victims involved in the volatile flammable liquids incidents, 488 (73 percent) were hospitalized, 50 ( 7 percent) died in the hospital; and one was dead on arrival. Another 102 victims were'treated and released while 9 only required first aid at the scene of the accident.

More than 75 percent of the children through the age of 12 and youth through the age of 20 were hospitalized for treatment of their injuries. The majority of the remaining infants and toddlers died in the hospital, while most of the remaining older children and youth were treated and released from the hospital.

Approximately 75 percent of the adults were hospitalized for treatment of their injuries. Most of the remaining adults in the 21-45 and 4665 age groups were treated and released while the majority of the remaining elderly adults were reported to have died in the hospital. 
Table 13. Injury Disposition of Victims by Age Groups and Sex

a. Volatile Flammable Liquids

\begin{tabular}{|c|c|c|c|c|c|c|c|c|c|c|c|c|c|c|c|}
\hline \multirow[b]{2}{*}{ Disposition } & \multicolumn{2}{|c|}{$0-5$} & \multicolumn{2}{|c|}{$6-12$} & \multicolumn{2}{|c|}{$13-20$} & \multicolumn{2}{|c|}{$21-45$} & \multicolumn{2}{|c|}{$4 \overline{6-65}$} & \multicolumn{2}{|c|}{$66+$} & \multicolumn{2}{|c|}{ Unknown } & \multirow[b]{2}{*}{ Total } \\
\hline & M & $\mathrm{F}$ & M & $\mathrm{F}$ & M & $\mathrm{F}$ & M & $\mathrm{F}$ & M & $\mathrm{F}$ & M & $\mathrm{F}$ & M & $\mathrm{F}$ & \\
\hline $\begin{array}{l}\text { First Aid Only } \\
\text { Treated \& }\end{array}$ & - & - & 1 & - & 2 & - & 2 & 1 & 1 & 1 & - & 1 & - & - & 9 \\
\hline Released & 3 & 1 & 11 & 3 & 22 & 3 & 31 & 8 & 16 & 2 & - & 1 & 1 & - & 102 \\
\hline Hospitalized & 18 & 10 & 101 & 17 & 100 & 16 & 120 & 21 & 52 & 9 & 14 & 9 & 1 & - & 488 \\
\hline $\begin{array}{l}\text { Dead on Arrival } \\
\text { Died in Hos- }\end{array}$ & - & - & - & - & - & - & - & - & - & - & - & 1 & - & - & 1 \\
\hline $\begin{array}{l}\text { Pital } \\
\text { No Treatment }\end{array}$ & 5 & 5 & 6 & 2 & 5 & 1 & 9 & 3 & 5 & 4 & 4 & 1 & - & - & 50 \\
\hline Necessary & - & - & 1 & - & - & - & - & - & - & - & - & - & - & - & 1 \\
\hline Total known & 26 & 16 & 120 & 22 & 129 & 20 & 162 & 33 & 74 & 16 & 18 & 13 & 2 & - & 651 \\
\hline Unknown & 1 & - & 1 & 1 & 4 & 1 & 4 & 1 & 1 & - & - & - & 2 & 1 & 17 \\
\hline Total & 27 & 16 & 121 & 23 & 133 & 21 & 166 & 34 & 75 & 16 & 18 & 13 & 4 & 1 & 668 \\
\hline
\end{tabular}

b. Grease and Other Less Volatile Flammable Liquids

\begin{tabular}{|c|c|c|c|c|c|c|c|c|c|c|c|c|c|c|c|}
\hline \multirow[b]{2}{*}{ Disposition } & \multicolumn{2}{|c|}{$0-5$} & \multicolumn{2}{|c|}{$6-12$} & \multicolumn{2}{|c|}{$13-20$} & \multicolumn{2}{|c|}{$21-45$} & \multicolumn{2}{|c|}{$46-65$} & \multicolumn{2}{|c|}{$66+$} & \multicolumn{2}{|c|}{ Unknown } & \multirow[b]{2}{*}{ Total } \\
\hline & M & $\mathrm{F}$ & M & $\mathrm{F}$ & M & $\mathrm{F}$ & M & $\mathrm{F}$ & M & $\mathrm{F}$ & M & $\mathrm{F}$ & M & $\mathrm{F}$ & \\
\hline Treated \& & & & & & & & & & & & & & & & \\
\hline Released & - & - & - & - & - & 1 & 4 & 5 & - & 1 & 1 & 2 & - & - & 14 \\
\hline Hospitalized & - & 1 & - & - & 3 & - & 3 & 5 & 1 & 6 & - & 1 & - & - & 20 \\
\hline $\begin{array}{l}\text { Died in Hos- } \\
\text { pital } \\
\text { No Treatment }\end{array}$ & - & - & - & 1 & - & - & - & - & - & - & - & 2 & - & - & 3 \\
\hline Necessary & - & - & - & - & - & - & - & 1 & - & - & 1 & - & - & - & 2 \\
\hline Total Known & - & 1 & - & 1 & 3 & 1 & 7 & 11 & 1 & 7 & 2 & 5 & - & - & 39 \\
\hline Unknown & - & - & - & - & - & - & - & - & 1 & - & - & - & - & - & 1 \\
\hline Total & - & 1 & - & 1 & 3 & 1 & 7 & 11 & 2 & 7 & 2 & 5 & - & - & 40 \\
\hline
\end{tabular}


Table 13. Injury Disposition of Victims by Age Groups and Sex (Continued)

c. Gas

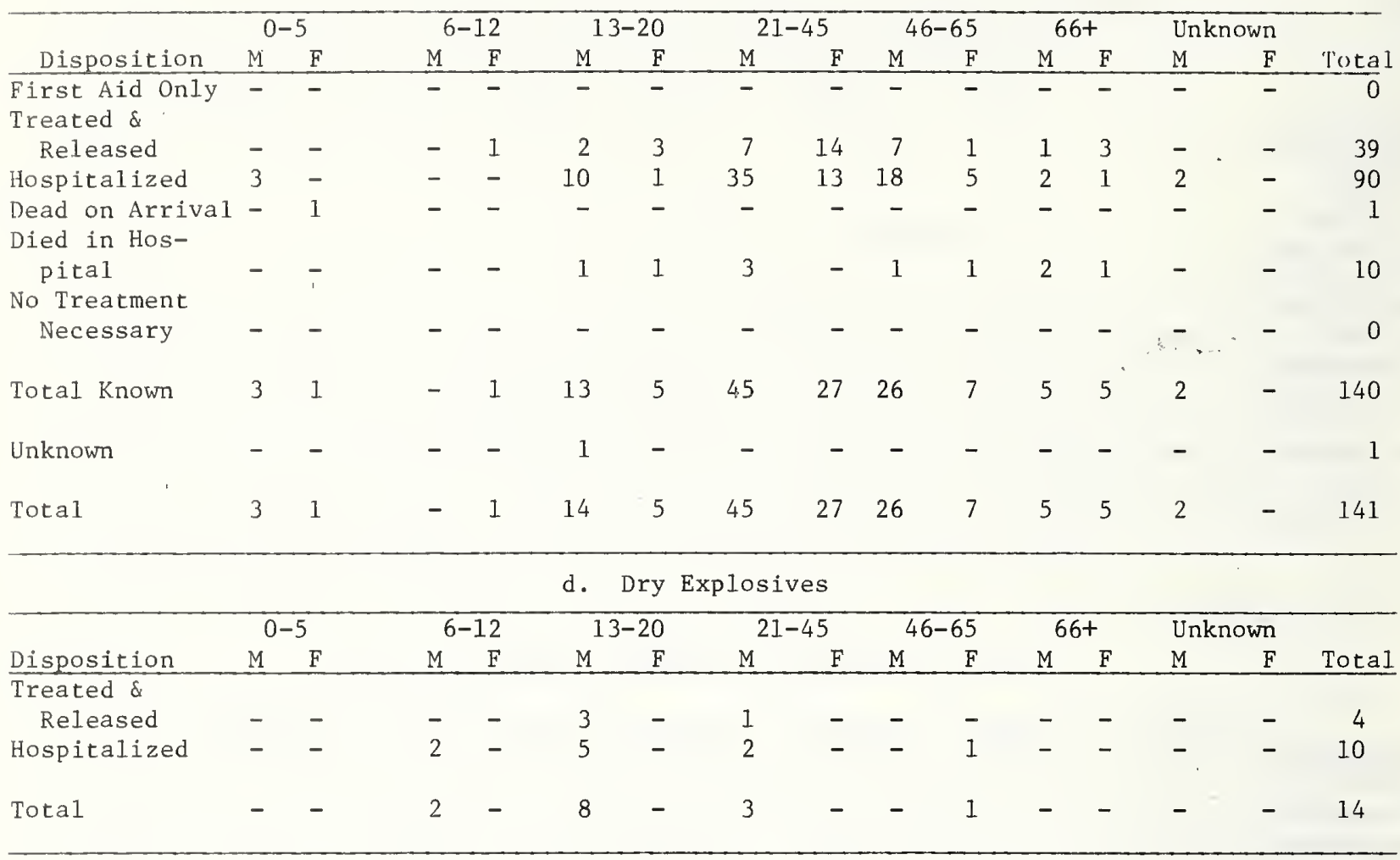




\subsubsection{Grease and Other Less Volatile Flammable Liquids Category}

Twenty (50 percent) of the 40 victims involved in the grease and other less volatile flammable liquids incidents were hospitalized; 80 percent were adults age 21 and over. Three ( 8 percent) of the victims in the incidents were known to have died in a hospital; two were elderly and one was a child. Thirty-five percent of the victims, all from the youth and adult age groups, were treated at a hospital and released while for the remaining two victims, both adults, no treatment was necessary.

\subsubsection{Gas Category}

Ninety (64 percent) of the 141 victims from the gas incidents were hospitalized; 84 percent of these victims were adults age 21 and over and 12 percent were youth ages 13-20. Eleven ( 8 percent) of the victims were reported to have died; the 7 victims from the youth and adult age groups died in a hospital and the eighth victim, a toddler, was dead on arrival at the hospital. Thirty-nine $(28$ percent) of the victims were treated at the hospital and released.

\subsubsection{Dry Explosives Category}

Ten ( 71 percent) of the 14 victims involved in dry explosives incidents were hospitalized for treatment of the burn injuries they sustained. The remaining 4 victims (29 percent) were treated at a hospital and released.

\section{SUMMARY AND DISCUSSION}

In a FFACTS data base of 3,043 cases, 863 victims were involved in 832 separate incidents where intermediary materials in the form of flammable liquids, gas, and other explosive materials were present in the ignition sequence. It should be remembered that the incidents selected for FFACTS do not constitute a statistically representative sample of all all fabric fire accidents in the United States and that percentages estimated from small sample sizes are subject to large uncertainties. The FFACTS data base was used for this study even though it is structured to collect detailed information about fabrics involved in fire incidents. The information obtained from these case history reports concerning flammable liquids, gas, and other explosive materials was additional information provided by the field investigators in their attempt to depict as accurately and precisely as possible the sequence of events which led to the ignition of fabric items. Therefore, the information contained in this paper relates to fabric-ignited fires only and cannot be considered as typical or conclusive of flammable liquid or explosive types of ignitions. 
Of the four intermediary material categories studied, volatile flammable liquids were reported in 77 percent of the incidents and gas was reported in 16 percent of the incidents. Grease and other less volatile flammable liquids and dry explosives, collectively, represented 7 percent of the incidents. Gasoline was the single most frequently reported intermediary material representing 462 (56 percent) of the 832 incidents studied.

Male victims outnumbered females more than 3 to 1 in these incidents. Males dominated the volatile flammable liquids, gas, and dry explosives categories where most of the activities which led to the ignition sequence are traditionally considered male oriented. Female injuries dominated in the grease and other less volatile flammable liquids category in a nearly 2 to 1 ratio over the males. Most of these incidents involved kitchen ranges where food preparation activities generally triggered the ignition sequence.

When the victims of all of the incidents studied were divided into six age groups, young adults in the 21-45 age group were found to be involved most frequently followed by youth, ages 13-20. Young adults and youth are often involved in many tasks for which it is necessary to become involved with flammable liquids and/or gas, but older adults, particularly those in the 46-65 age range, are involved frequently with many of these tasks also. One possible explanation for the high injury rates for the young adults and youth could be a lack of knowledge or experience in performing the tasks and/or working with flammable liquids and other explosive products. For the youth this explanation can be expanded to include "playing" or "experimenting" with these dangerous materials.

The frequency of involvement for the youngest and oldest age groups was rather low when compared to the other age groups used in this study. However, there was a tendency for these victims to sustain more severe burn injuries, which resulted either in more extensive medical treatment or death. For the young, this may indicate the lack of development of motor skills and communicative abilities necessary to effectively handle a fire situation. 13 These skills and abilities are better developed in older children as reflected in the data presented throughout this paper for children in the 6-12 age range. In general, the activities reported for these children were more sophistocated, the burn injuries sustained less severe, and the medical attention required less drastic. 14 For the elderly, the absence of involvement in these types of incidents may indicate deterioration in manual dexterity and physical coordination which would prevent them from becoming involved in activities connected with these hazardous products.

13 Tyrrel1, E. A., Fire Accidents Involving the Ignition of Sleepwear Worn by Children Under the Age of Three, Nat. Bur. Stand. (U.S.), Technical Note 815 (Feb. 1974).

${ }^{14}$ Another comprehensive study relating the accident patterns for victims in these age groups is reported in Tyrre11, E. A., Gasoline and Gasoline Container Fire Incidents, Nat. Bur. Stand. (U.S.), Technical Note 850 (Jan. 1975). 
For these 832 incidents, 466 fabric items were known to have been first-to-ignite items. Street wear, primarily shirts/blouses, was the group of fabric items reported as being first-to-ignite most frequently for the volatile flammable liquids, gas, and dry explosives categories. Interior furnishings, mostly draperies/curtains, were reported most frequently as being first-to-ignite in the grease and other less volatile flammable liquids category.

Forty-eight percent of the first-to-ignite fabric items reported in the volatile flammable liquids incidents and 30 percent of those in the grease and other less volatile flammable liquids incidents were contaminated with a flammable liquid at ignition. Seventy-one percent of these contaminated fabrics were street wear garments in the volatile flammable liquids incidents while only one item from the interior furnishings fabric group in the grease and other less volatile flammable liquids incidents was contaminated.

Similar percentages for fabric contamination were observed in these two categories of incidents when order of ignition was disregarded. The distribution of injury rates for the victims of these 2 categories by age group and sex did not indicate that the severity of the burn injury sustained increased with fabric contamination. In general, most of these victims sustained burn injuries covering only 1-10 percent of their bodies. Many of the victims of the gas and dry explosives incidents, however, sustained burn injuries covering 31-60 percent of their bodies. This level of injury was probably influenced by the fact that these incidents were caused by an explosion.

The greatest percentage of the victims for all categories were hospitalized for treatment of their burn injuries. No more than 8 percent of the victims -- all from the first 3 categories of intermediary materials -- were reported to have died in a hospital. Many of the victims who died in the hospital or were reported dead on arrival were infants and toddlers, and elderly adults.

Educational programs prepared for the various communications media are needed to educate the public in not only the properties and characteristics of the many flammable liquids and explosive products found on the market but also the manufacturer's intended use of these products which has made them so readily accessible to the consuming public. One of the most effective ways of capturing the attention of the public is to describe or show the consequences of using these products with indifference -- the severely burned or maimed victim. Perhaps only if the public understands the magnitude of the results of casually or erroneously using these products will it be receptive to the information prepared to explain how to properly select, use, and store these hazardous materials in the home. 15

T5Tyrrell, E. A., Gasoline and Gasoline Container Fire Incidents, Nat. Bur. Stand. (U.S.), Technical Note 850 (Jan. 1975). 


\section{APPENDIX A. THE FLAMMABLE FABRICS ACCIDENT CASE AND TESTING SYSTEM (FFACTS)}

The National Bureau of Standards (NBS) Flammable Fabrics Accident Case and Testing System (FFACTS) was developed under the mandate of the Flammable Fabrics Act, as amended in 19671. The System was implemented in 1970 with case histories dating back to 1967. The Consumer Product Safety Act of 19722 transferred the responsibilities of the Flammable Fabrics Act to the new Consumer Product Safety Commission (CPSC), but NBS continues to provide technical support to the Commission which, until December 1974, included the maintenance and analysis of data incorporated in FFACTS.

The primary source of the accident data incorporated in the FFACTS data base is in-depth investigative reports on flammable fabric accidents supplied to NBS by the Bureau of Product Safety, Food and Drug Administration (FDA), prior to the inception of CPSC. Using report forms originally developed by NBS and FDA, investigators from FDA and other participating organizations followed and reported on accidental fires involving fabric products from around the country. This activity is currently conducted by the 14 CPSC Area Offices around the country. These reports, together with any available remains of fabric products involved, were sent to the Office of Information and Hazard Analysis, Center for Fire Research (NBS), for processing. If the reports met the FFACTS requirement of relevance and adequacy, the fabrics, if any, were analyzed for fiber composition, fabric construction, and weight. If appropriate test methods existed, flammability characteristics for these fabrics were also determined. The information from the accident reports was then reviewed in light of results of the laboratory tests, coded, and entered into the FFACTS computerized data base. Some 130 different data elements can be coded for an incident.

It should be noted that the incidents chosen for FFACTS are not selected on a statistical basis and therefore, do not constitute a statistically representative sample of, all fabric fire accidents in the United States. However, they do represent events investigated without known preference and, therefore, may be roughly representative of incidents reported to the agencies from which the CPSC and others obtain accident data.

The Flammable Fabrics Act, 81 Stat. 568, 15 U.S.C. 1191, as amended and revised Dec. 14, 1967.

${ }^{2}$ Consumer Product Safety Act. 86 Stat. 1221, 15 U.S.C. 2064B, May 14, 1973. 
B.1. IGNITION SOURCES

\section{HEATERS}

1. Furnace (gas)

2. Space heater

3. Hot water heater

4. Unspecified heater

5. Other heater

APPLIANCES

6. Clothes dryer

7. Electric range

8. Gas range

9. Light bulbs

10. Camp stove

11. Other

\section{OTHER OBJECTS}

12. Electrical wiring

13. Extension cord

14. Lantern/candles

15. Open fire (unspecified)

16. Fireplace

17. Camp fire

18. Incinerator

19. Charcoal grill

20. Hot coals or smoldering sticks

21. Smoking materials (unspecified)

22. Cigarette

23. Cigar/pipe

24. Matches or lighter

25. Matches

26. Lighter

27. Cutting/welding torch and other special ignition sources

28. Other work tools

29. Combustion engine

30. Eireworks

31. Sparks or shorts

32. Miscellaneous

33. Unknown 


\section{B.2. IGNITION-CAUSING ACTIVITIES}

1. Playing with a flammable liquid and an ignition source

2. Playing with a flammable liquid

3. Playing with matches or lighter

4. Playing with open fire

5. Starting or tending an open fire type 1 (camp fire, fireplace, grill, incinerator, etc.)

6. Starting or tending an open fire type 2 (bonfire, fire to clear brush, leaves, etc.)

7. Stirring, stomping, or disturbing an open fire

8. Standing by an open fire (flammable liquid on clothes)

9. Warming self

10. Standing near a flammable liquid

11. Standing near explosive or ignition source - gas appliance (flammable liquid may be on clothes)

12. Transferring a flammable liquid

13. Carrying or transporting a flammable liquid

14. Refueling power machinery and vehicles

15. Spilling or splashing a flammable liquid

16. Knocking over or dropping container of a flammable liquid

17. Cleaning or repairing machinery or equipment

18. Priming carburetor

19. Using machinery or equipment (using or attempting to use lanterns, appliances, vehicles, etc., when malfunctioning or explosion occurred)

20. Using welding torch, soldering iron, or other work tools which resulted in being ignition source equipment

21. Using matches or lighter

22. Using a flammable liquid as a cleaning agent (solvent)

23. Using a flammable liquid as an exterminating agent

24. Using a flammable liquid to ignite a heating source

25. Smoking

26. Driving or riding in automobile, tractor, motorcycle, airplane, etc. (collision, etc.)

27. Helping another person involved in an ignition incident

28. Suspected arson

29. Assault/suicide

30. Miscellaneous

31. Unknown 
NBS.114A (REV. 7.73)

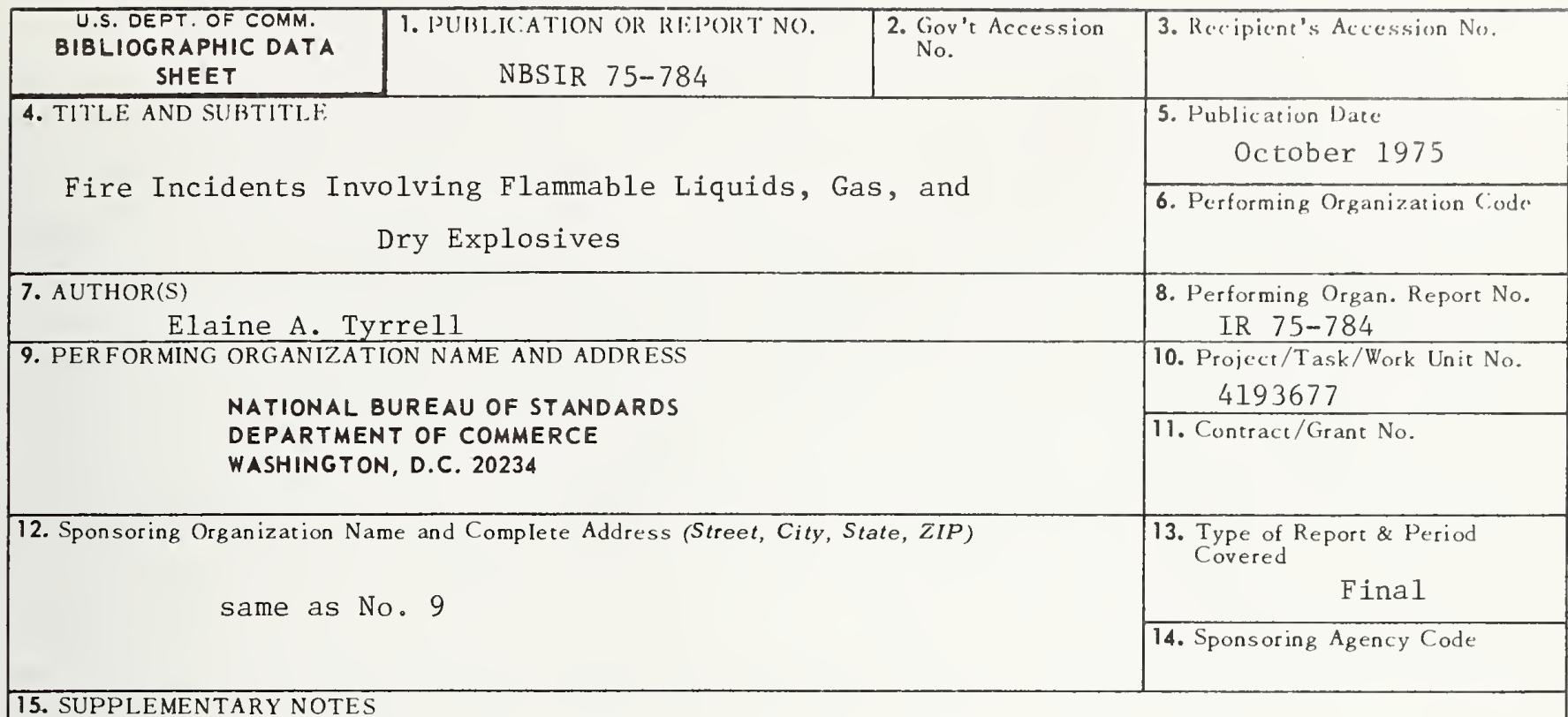

15. SUPPLEMENTARY NOTES

16. ABSTRACT (A 200-word or less factual summary of most significant information. If document includes a significant bibliography or literature survey, mention it here.)

From the NBS Flammable Fabrics Accident Case and Testing System as of December 1973, flammable liquids, gas, and dry explosives were found to be involved in 832 incidents, injuring 863 victims. Volatile flammable liquids represented 77 percent of the incidents; 72 percent of these liquids were gasoline. Male victims outnumbered females more than 3 to 1 . Young adults, ages 21-45, and youth, ages 13-20, were injured most frequently. Children and youth were injured primarily through what was considered as play activities. Adults generally were injured while engaged in activities traditionally considered as being oriented to the particular sex involved. Streetwear, particularly shirts/blouses, was reported most frequently as igniting first. Thirty-six percent of the fabrics represented in these incidents were contaminated with a flammable liquid. Most of the victims sustained burn injuries covering 1-10 percent of their bodies; only 6 percent sustained burn injuries covering 61 percent or more of their bodies. Most of the victims were hospitalized for treatment of their injuries. Although the very young and the elderly were involved in these incidents less frequently than other age groups, they generally were burned more severely and represented 46 percent of the victims who died in the hospital or were dead on arrival.

17. KEY WORDS (six to twelve entries; alphabetical order; capitalize only the first letter of the first key word unless a proper name; separated by semicolons) Accidents; burn injuries; burn severity; explosives; fabric fires; FFACTS; flammable liquids; gas; gasoline; ignition-causing activities; ignition sources; injury disposition.

\section{AVAILABILITY

$$
\text { X. Unlimited }
$$

— For Official Distribution. Do Not Release to NTIS

Order From Sup. of Doc., U.S. Government Printing Office Washington, D.C. 20402, SD Cat. No. C13

X. Order From National Technical Information Service (NTIS) Springfield, Virginia 22151

\begin{tabular}{|l|c|}
\hline $\begin{array}{l}\text { 19. SECURITY CLASS } \\
\text { (THIS REPURT) } \\
\text { UNCL ASSIF IED }\end{array}$ & 21. NO. OF PAGES \\
\hline $\begin{array}{l}\text { 20. SECURITY CLASS } \\
\text { (THIS PAGE) }\end{array}$ & 22. Price \\
UNCLASSIFIED & $\$ 35$ \\
\hline
\end{tabular}



